\title{
Nigerian Newspaper Readership's Response to Discourses on Healthy Life Style for Disease Prevention
}

\author{
Allen Nnanwuba Adum \\ Department of Mass Communication, Nnamdi Azikiwe University, Awka, \\ Anambra State, Nigeria \\ Ogochukwu Ekwenchi \\ Department of Mass Communication, Nnamdi Azikiwe University, Awka, \\ Anambra State, Nigeria \\ Chioma Agbasimelo \\ Department of Mass Communication, Tansian University, Umunya, \\ Anambra State, Nigeria \\ Perpetual Chinonye Umeaku \\ Department of Mass Communication, Nnamdi Azikiwe University, Awka, \\ Anambra State, Nigeria
}

\begin{abstract}
This study examined how Nigerian Newspaper readership responded to discourses on healthy lifestyle for disease prevention. In line with this, five research questions were posed for investigation as follows: 1 . To what extent do Nigerian Newspapers discuss healthy lifestyle for prevention of disease? 2. Who among the target audience are exposed to these messages? 3. How many of the readers are knowledgeable of the 'safe' habits necessary to maintain a healthy state? 4 . What is the readers' disposition towards the health discourses in the Nigerian Newspapers? 5. To what extent do they take health action as suggested in Newspaper health discourses? The study involved triangulation. Newspaper discourses on healthy lifestyle were content analyzed to determine the extent of newspapers' discourses. The Survey data was collected from 386 civil servants drawn from three selected state secretariats in south east Nigeria. Results from analyzed data showed the presence of healthy lifestyle discourses in Nigerian newspapers in a significant manner. The data analyzed revealed that the civil servant respondents studied read the newspapers and were highly exposed to Newspaper discourses on the subject matter. The civil servants also demonstrated high knowledge of the safe habits necessary to maintain a healthy state. The respondents were also found to have good disposition towards the message but not all the civil servants took adequate action to maintain a healthy state.
\end{abstract}

Keywords: Discourses on healthy life style, readership, disease prevention

DOI: $10.7176 / \mathrm{IKM} / 9-6-06$

Publication date: June $30^{\text {th }} 2019$

\section{INTRODUCTION}

It is a truism that the world's population is threatened with an appreciable number of diseases of various kinds; most of these constitute major public health concerns. Illnesses such as heart diseases, stroke, cancer, chronic respiratory disease and diabetes, are by far the leading causes of mortality in the world, representing $63 \%$ of all deaths (World Health Organization (WHO; 2005). Also, (WHO; 2005) document titled "Chronic Disease: A vital Investment" concluded that the majority of deaths worldwide for all ages are due to chronic diseases adding that cardiovascular diseases (mainly heart disease and stroke) are responsible for 30 percent of all deaths while cancer, chronic respiratory diseases and diabetes are also major causes of mortality. According to WHO statistics, out of the 36 million people who died from chronic diseases in 2008, 9 million were under 60 to 90 
percent of these premature deaths occurred in low and middle income countries where most countries of Africa, including Nigeria belong.

For decades, advances in medical science and technology have made and have continued to make enormous difference to our health and quality of life. In the event of illness, our chances of survival are much improved and more people than ever before are living to an advanced age. However, there has also been a growing realization that science and medicine do not have all the answers and that each individual can influence his or her own health through simple lifestyle choices (Okonkwor, 2015).

In view of this, there seem to be a growing focus on the need to maintain a healthy lifestyle in the interest of good health and physical wellbeing. Most people are subjected from infancy and childhood up to adulthood, to imperatives as to the quantity and types of food they should eat in order to maintain good health and physical wellbeing. This is even more pronounced with the high rate at which people are affected with illnesses such as cancer of different kinds, hypertension, stroke, diabetes, among others. These diseases, experts have explained, are often caused by poor lifestyle and wrong food choices. For example, in a lecture held in Ibadan on the $4^{\text {th }}$ of January, 2015 and entitled "prevention, Management and Possible Control of Terminal Diseases, Dr. Yusuf Issa, a German-trained expert in complementary and Alternative Medicine attributed most chronic health problems to food intakes. According to him majority of common illnesses are caused by factors that are completely in one's control. "The fact is that you can take charge of your health and feel better than you ever had in your life," he said.

Health promoters, medical and health professionals as well as health reporters have articulated the dictates concerning the appropriateness of food or regimen, in relation to establishing and maintaining good health. In the views of Lupton and Chapman (1995), these discourses constitute a dominant belief system which appears to be evident with categorizing certain foods as 'healthy' (or 'good') and others as 'unhealthy' (or 'bad') or certain behaviours as healthy and others unhealthy. As a consequence, there appears to be some kind of tension between the need to eat certain types of 'good' food for health reasons, and the need to eat 'bad' foods or indulge in 'poor' lifestyles just for comfort and pleasure.

The mass media are important sources for the reproduction of dominant discourses and practices around food and health, acting as mediators between medico-scientific and lay knowledge (Lupton and Chapman, 1995). Thus, they can shape the way we think and our belief about health as well as our health practices (Uwom and Oloyede, 2014). There have been found, in recent times, in most media platforms especially the print media, a number of discourses on food scares around the content of certain foods such as preservatives, bacteria, chemicals, sugar, fat and cholesterol. The messages are often advising people to stay away from the bad food and/or promoting the right foods, fruits and drinks to take instead, for the purpose of maintaining a healthy body. Other aspects have also included some exercise regimens among other 'pro-health habits' that should be undertaken for both prevention and management of diseases.

Interestingly, most of these messages have become imperative to satisfy peoples' growing crave for adequate information and knowledge on health matters, including healthy lifestyle practices, preventive health measures, health conditions and diseases; all needed to be in good health. To this end, health communication scholars and researchers have agreed that the mass media have been and are helpful in creating awareness, accelerating information flow and mobilizing the populace towards attainment of national goals and aspirations to ensure a total transformation of the society. With this in mind, it is important to explore how people react to this information and whether they take positive action for their wellbeing. 'People' here refer to Newspaper readers in the South East region of Nigeria, which will constitute the area for this study.

\subsection{South East: A Contextualization}

South East became the name of one of the six geo-political zones in the Nigeria in the 1990s; it comprises Abia state, Anambra state, Ebonyi state, Enugu state and Imo state. The local language in the region is Igbo.

The Igbos of South East Nigeria are one of the most dominant groups in West Africa. "The Igbo world is not only a world in which people strive for equality, it is one in which change is constantly expected" (Uchendu, 
1963).

The Nigerian society is a multi-ethnic and culturally pluralistic society with diverse practices and practitioners to meet a qualitative livelihood, which health is very fundamental. Everyone in the society desires a total healthy livelihood in order to purposefully contribute to societal growth and development effectively (Ojua, 2006).

Thus, in a country where a larger part of its population is threatened by chronic health problem, the search for preventive health advice and curative health methods can only be on the increase. It is for this reason and to maintain the quality of health that many researchers have sought to look into the peculiar curative health behaviours among ethnic groups in Nigeria, prominent among whom studied is the South East region. The search for potent or effective curative health methods including the use of trado-medical outfits (the native healers and faith healers); and orthodox medicine and the rise of their practitioners is not unconnected to the high rate of diseases ravaging the human body and the high number of people affected by these illnesses. Thus, while this is known, studying how people living in this region respond to mediated information, especially through the newspapers, on how to prevent these diseases, especially, those that are preventable by the choices we make, will be of relevance to the body of research on health and communication.

\section{STATEMENT OF THE RESEARCH PROBLEM}

The eight Millennium Development Goals (MDGs) to which 189 world leaders subscribed to in 2000 bother on health issues and underscore the importance of healthful living and healthcare provision in the affairs of the human population; so, also are the SDGs. But several health reviews indicate that not much seems to have been achieved in the realization of these goals. A report by the Nigerian Health Review (2006) says Nigeria and other sub-Sahara African countries are lagging behind in all the MDGs. According to the Health Reform Foundation of Nigeria (HERFON) in the Nigerian Health Review (2006) "recent assessment of the health of the Nigerian population indicates that the health situation in Nigeria and of Nigerians is dismal and efforts to change the situation over the years have been insignificant." In another review of the health situation in Nigeria, the Federal Ministry of Health acknowledged that "the health system in Nigeria and the health status of Nigerians are in a deplorable state. For example, it is estimated that more and more Nigerians suffer from chronic illnesses, some of which are killing more Nigerians than the dreaded HIV/AIDS.

As a consequence, experts have identified low awareness, lack of physical exercise, increased consumption of foods high in fats and sugars, unhealthy eating habits and other unhealthy behaviours as reasons why manyf Nigerians suffer illnesses. However, to further prevent diseases, they equally recommended that people should exercise regularly and make healthy lifestyle choices at all times.

Interestingly, most of these preventive measures often constitute the gamut of mass media messages promoting healthy eating and lifestyle. For instance, newspapers and magazines through their specialized reports seem to be promoting healthy living and lifestyle with the view to mobilizing the populace to achieving a healthy state. But despite the presence of these communication efforts, chronic diseases seem to be on the increase.

It then becomes imperative to examine the responses of the Nigerian newspaper readers towards healthy lifestyle discourses for prevention of diseases. The idea is to determine whether their exposure to these messages has caused them to improve on their eating habits and lifestyle, as a way of preventing developing health conditions.

\section{PURPOSE OF THE STUDY}

Against the backdrop of the research problem, this study examined the responses of Nigerian newspaper readership towards discourses on healthy lifestyle for disease prevention. The specific objectives were to ascertain:

- The extent to which Nigerian newspapers discuss healthy lifestyle for prevention of diseases

- Whether the target audience were exposed to these messages

- Whether they were knowledgeable of the 'safe' habits necessary to maintain a healthy state.

- The audience disposition towards the health discourses in Nigerian Newspapers

- Whether they took health actions as suggested in Newspaper health discourses.

\subsection{Research Questions}

In order to aid the investigation of the research problem, the following research questions were posed:

- To what extent do Nigerian Newspapers discuss healthy lifestyle for prevention of disease?

- Who among the target audience are exposed to these messages? 
- How many of the readers are knowledgeable of the 'safe' habits necessary to maintain a healthy state?

- What is the readers' disposition towards the health discourses in the Nigerian Newspapers?

- To what extent do they take health action as suggested in Newspaper health discourses?

\section{NIGERIAN NEWSPAPERS AND THEIR INFLUENCE}

Nigerians are constantly bombarded with messages from a multitude of sources and wide range of issues bothering on health, politics, environment, education, entertainment, among others. Newspapers provide written forms of communication that allow for the discussion of these issues.

Undoubtedly, Nigeria is one of the African countries which recognize freedom of information as an essential part of democracy. Hence, this has led to the proliferation of Nigerian newspapers and other news sources. However, one unique thing worthy of note is that Nigerian newspapers comprise interesting dailies, periodicals, tabloids which reflect the culture, political and social landscape of the country, observes Adeniyi (2007). Some of the popular newspapers recognized in Nigeria include The Punch, The Guardian, Vanguard, The Sun, Daily Independent, The Nation, Daily Independent, Nigerian Tribune, This day, Daily Champion, Leadership, among others.

The newspapers, just like other media forms exert some form of influence on the society. However, the extent, type or level of influence has constantly been debated among scholars in both academic and professional parlance. This debate has spanned through the ages.

The information need in the society has continued to grow. This need is such that man can hardly function well, determine his course in life and most importantly, make informed decisions and well informed choices without some form of communication. The mass media, especially the newspapers are highly influential in this course. It is often cited in the media's ability to direct and redirect attention of the public towards and away from important issues, accord importance to places, people and issues and instill and build public perception towards societal affairs. This is encased in the agenda setting function of the media.

There is no modern society that can do without good newspapers, despite the advancement in new media technology such as the internet that has made media convergence possible. Also, despite the economic realities and readership decline that seemed to be threatening the growth of the print media, the thriving of some viable newspapers in these recent realities are evident. Thus Hallin 2000, concerning this idea which supports the readership hypothesis, writes that:

Newspapers are doing what they must to respond to a dangerous decline in readership, becoming more responsive in an effort to hold on to 'customers' who can choose between a number of sources of information...newspaper readership is indeed declining...Given these facts, newspapers had no choice but to find out what modern readers wanted and give it to them (p. 222).

Thus, placing Hallin's words in proper perspective, the implication of serving the readers' choice is apparent in most Nigerian newspapers and has thus given these papers some kind of colourations. These includes, among others, short stories, colour, graphics and a shift in the agenda away from solely traditional public affairs news and issues to lifestyle features and news one can use. Ige (2013) agrees to this thought when he said that in today's business driven newspapers, news stories are shorter, colour and graphics are generously used on the sports pages and business pages feature abundance of graphs, dealing with issues that affect the economy and features; articles on 'celebrities' are common place.

The role of the newspapers in fostering developmental goals cannot be over emphasized. Kadiri (2011) contends that the use of mass media for the speedy transformation of the nation from poverty to a dynamic state of economic growth, social equality and fulfilment of human potentials are indeed recognized in different nations but that they must be put to proper use to achieve this. Although, broadcast media have been adjudged to be the most potent in development communication efforts (Moemeka, 1991), the print media have their own advantages. As noted by Moemeka (1991), the print media have an enduring characteristic which neither the radio nor the television has. He adds that the newspaper can be read and re-read at one's convenience, thus allowing fuller and better understanding of the message contents. The newspapers according to him can also be stored away for future use, thus making for the preservation of materials that are considered important for future reference.

Ogbondah (1994) notes the statement by Olu Onagoruwa: "The power of the press is the power of the written word - its first quality is performance. Unlike the spear arrow or the fired bullet, a written word can be in ages. In other words, newspaper readership has a lasting memory of whatever interesting that appears on the pages." 
The print media, particularly the medium of newspaper has become the major source of information dissemination over the years, and also the major means of political, health and social mobilization in Nigeria. Newspaper has the ability to inform, educate, entertain, enlighten and mobilize the public. That is why the government and other private bodies and individuals give much attention to it and use it to disseminate their ideas.

Newspapers give us reliable information about issues bothering on health, politics and education. This is because, unlike the internet which is faced with credibility problems, the mass media especially the newspaper organizations have professionals who work in the organizations and are guided by their journalistic tenets and training to provide accurate and complete information about an issue. It is in the Nigerian newspapers today that you find on daily bases, articles written by intelligent people as well as a variety of expert opinions on a variety of issues. Some of these articles have suggested ways and means by which we can combat tribalism, fraud, serious crimes, corruption, personal or public health problems, as well as other social vices that disintegrate the fabrics of the society.

All these still remain the important content of an average Nigerian daily; because, among other things, it is still believed to influence its readers by shaping their thinking and exposing them to things they know nothing about.

\section{FACTORS THAT DETERMINE TOPICS COVERED IN NIGERIAN NEWSPAPERS}

Newspaper production has come a long way to where it is today. It has indeed, undergone series of evolution, evolving from the tablet form to a paged news sheet and to what we now call modern newspaper. The same way the production process evolves, so the contents have been diversified over time to accommodate different audience members' varying needs and interests.

Newspapers have different classifications. One could be by nature of dominant newspaper interest. The interest may be sports, fashion, religion, business, gender etc. In Nigeria, most of the special interest publications come in the form of magazines with few newspapers trailing behind. Examples of such special appeal-cum interest newspapers are found largely in the areas of business and sports, some of such publications include Business Day, Complete Sports and Kick Off

Just like every media form, the source of newspaper coverage come from beats. According to Nwodu (2006, p.87) news beat are simply "special interest areas or places where reporters are assigned to for purpose of continuous coverage. Hence, once a beat is assigned to a reporter, he/she automatically assumes the responsibility of ensuring daily coverage of activities in that beat. There is a limit to what can go for news from that beat.

News from the beat must therefore come from a specific news area. News beat is therefore very crucial in news gathering and production. The relevance of news beat in the process of news gathering, processing and production according to Nwodu (2006, p. 88) includes among others:

* It enhances day to day work of news organisations by making news readily available.

* It boasts the quality and quantity of news carried by news organisation.

* It leads to specialisation in news reporting. The more a reporter covers a special beat the more he specialises in the coverage of such beat.

Thus, having discussed this, it is important to note that the topics that appear in the newspapers are in the first place, dependent on the particular type of beat assigned to the reporters.

\subsection{Beats or specialized areas covered in Nigerian newspapers}

As classified by Nwodu 2006, pp 88 - 89, they include:

\section{Police/Crime Beat}

This is where crime beat reporters usually go to obtain follow up information about judicial killing/assassination, arrest of hoodlums and robbery suspects, arson and sundry criminal activities.

\section{Judiciary or Court Beat.}

Reporters assigned to this beat often monitor and report updates of celebrated and/or controversial cases relating to misappropriation of public fund by top governments/public officials, rape, cases of divorce involving public figures etc. The judiciary beat reporter also reports social functions relating to judiciary and sundry matters like 
appointment of justice, judges and magistrates; call to bars; special court session for departed colleague; judicial panel of inquiry; human rights activities etc.

\section{Government House Correspondence}

The beat reporters cover government activities including their actions and inactions. Government here covers both the federal, state and local governments. So it is the responsibility of the beat reporter to always report the activities of the president, the governors, the local govt chairman, and their aids on regular basis.

\section{Legislative/Parliament Beat Reporter}

The national and state assemblies as well as the local government council are very important news sources. For this reason, newspaper edition in Nigeria and indeed elsewhere usually assign people to cover the activities happening in these assemblies and even in the constituencies and wards they represent.

\section{Science, Power and Mines.}

Many a time, the scientific and technological lives of a nation are faced with a number of developments and challenges. A breakthrough in medical/biological science, an advancement in a given aspect of technology, construction of dam, breakdown in power installations, appointments in ministry of science and technology; and so on are all newsworthy. It takes the effort of science, power and mines beat reporter to chronicle the activities for use in the production $n$ of newspaper.

\section{Agriculture}

This beat is also very crucial to newspaper audience in Nigeria. This is so because both subsistent and large scale mechanised agriculture are practiced in Nigeria. The agricultural beat reporters therefore work closely with Ministry of Agriculture and extension service in order to continuously report developments, issues and sundry activities in the industry.

\section{Education}

The beat reporter is concerned with continuous coverage of education Ministry; tertiary, secondary and primary educational institutions, issues and developments in the educational sector.

\section{Sports}

The reporter assigned to this beat, covers every aspect of sports and the ministry of sports, Because of the enormous interest Nigerians have in sports and the broad range of sporting activities that go on in the country, newspaper editors often assign reporters to cover different aspects of sporting activities. For instance, the reporter that covers football for a newspaper may differ from the one that covers marathon race or boxing etc.

\section{Entertainment, Recreation and Leisure}

Entertainment is a thriving business in Nigeria today. The home movies (both English and vernacular with or without English subtitle) are thriving. Comedians are waxing strong. The music industry is flourishing. Fast food industry is booming. In all, people are increasingly realising the importance of hanging out in recreation centres to be entertained and to give their lives good treat. So reporting entertainment and recreation has become a serious news beat where reporters are assigned to for frequent coverage. So the reporters report activities taking place in recreation centres with emphasis on: who is doing what in the industry, and the activities of the movie/entertainment stars.

\section{Banking /Finance}

As the name implies, this beat involves banking, insurance, assurance, stock market and sundry financial institutions that service business and economic activities of a country. So the beat reporter is saddled with the responsibility of covering events, development and challenges arising from this beat.

\section{Armed Forces/Para-Military Beat}

This beat covers the Army, Navy, Air force, Custom, Immigration, Civil Defence, Road Marshal (safety) and sundry institutions meant to protect the territorial integrity of the nation. In some newspaper organisations that have strong financial base and are well staffed, reporters are usually assigned to different arms of this beat. However, in some fledging ones, a reporter can cover all including police though not effectively.

\section{Foreign Affairs}

The beat reporter reports internal \& external affairs, diplomacy and polices. Often times, the beat reporter can travel to other nations to cover special events like UN Session, a country's General elections and other 
international issues of interest to the nation. The beat reporter most times monitors the wire service and extract international news he thinks will be of interest to the newspaper audience.

\section{Health/Hospital Beat}

The reporter of health/hospital beat undertakes the coverage of health related issues including activities taking place in the health ministry. He/she reports epidemic, discovery of new diseases, vaccines, new health challenges, healthy practices etc.

Suffice to add that some newspapers that have weekend editions most often have fashion and style reporters who cover lifestyle stories and events, personality and celebrity news. It is often in this edition that healthy living segments featuring most of the discourses in healthy lifestyle are published.

\subsection{Determining Issues of Coverage}

It is important to note that many seen news events take place on daily basis. As they occur, reporters face serious challenges as to which event to cover in preference to many others. This important phase of news or content gathering is not often approached with levity by the reporter. This decision is necessary given that an event does not become news merely because it occurred; it can only be substantive account of them (Nwodu; 2006 p.2).

Reporters often face serious problems deciding what to cover in preference to another. This is because the Nigerian newspaper reporter who is largely unethical considers a lot of interests in determining what to write and what not to write. First, he considers his own interest, his editor's interest and the interest of his organization while determining what to write. Omenugha and Oji (2008) that an organization is subjected to economic pressure and tries all means not to sink; so too are individual journalists. This view about Nigeria's news media including the newspapers seems to have garnered force as increasingly scholars suggest that news even when professionally selected is guided more by organizational needs than by professionalism (Omenugha and Oji; 2008). Put simply, consideration is given to an issue emanating from where the reporter expects fat envelope or where the editor had received gratification from cheap publicity seeker and insists a reporter should cover it or where the overall interest of the organization generally lies, often with advertiser's interest or owner's interest which may or may not serve the interest of the public.

However, apart from these ethical and gate keeping problems, experts have over the years, established parameters for gauging or determining which event should be covered in preference to others (MacDougal, 1977; Nwosu, 1996; Nwabueze, 2005 and Nwodu, 2006). It is important to note that these parameters are focused on the news determinants or values which emphasizes: Timeliness, Proximity, Prominence, Magnitude and Human interest/consequence

- Timeliness - is the event around which a potential news story will emanate timely?

- Proximity - how close or otherwise is the event likely to be to the newspaper audience?

- Prominence - how important is the potential news event and the personalities involved?

- Magnitude - how significant is the potential news event in terms of degree of occurrence? For instance it will be unprofessional to cover an averted accident in preference to one in which many people died.

- Human Interest/Consequence - what impact is the potential news likely to wield on the audience and places of occurrence?

It is important to note that while there are a wide range of beats covered in the Nigerian Newspapers, the above are salient principles that guide a reporter or an editor's choice of what eventually appears as content on a dayto-day basis.

In summary, newspapering in Nigeria involves a great deal and covers a wide range of different issues. But a common observation in a typical national daily is content segmentation in which the daily issue is divided into segments along the available beats and areas of specialties covered in the newspapers. One of these areas of specialties that are of interest is the health segment.

\section{HEALTH AS AN ISSUE COVERED IN NIGERIAN NEWSPAPERS}

Among the wide range of issues covered in the Nigerian Newspapers, Health is one of the specialized areas that is a common feature in Nigerian dailies. This may be as a result of the newspaper managers' realization of the prevalence of various health problems in Nigeria and their devastating consequences on the socio-economic status of the nation. They, among other things, have continued to report the efforts of the government at various levels and those of many international health and funding agencies to improve the health status of the individual 
members of the Nigerian society and the health sector at large. It is probably for this, that scholars have observed the central role the mass media play in informing the public about health and medical issues ( Thorson, 2006; Alexander, 2005; Moyer, 1995).

Similarly, Rodney and Torwel (2010) observe that print media especially perform necessary functions of providing information that will empower readers to action and are an alternative source people rely on for health information about new health risks, disease outbreaks, domestic and international alerts and healthy living. Rice (2001), Winnet and Wallak, 1996 concede to this view that the print and electronic news media are major sources of health information. Health news media coverage has an important role in shaping health behaviours at the population level (Pierce and Gilpin 2001, Niederdeppe and Frosch 2009) and influencing public health policy (Tong, Chapman, Sainsbury, Craig 2008). Here, the media is agreed to be highly complementary in the advancement of the health sector and to achieve good health outcomes among members of society (Bello, 2015).

As health coverage becomes more prevalent in the media especially the print as seen in some studies of Nigerian Newspaper coverage of health issues (Uwom and Oloyede, 2014), researchers have noted the inadequacy of such coverage which can hinder progressive and positive health outcomes for the good of individuals and society.

Thus, while the role of the news media in shaping public perception of health issues and public policy agendasetting and influencing public behaviour, cannot be contested, it then becomes essential for the health journalist, health care researchers and professionals to work together in assuring quality, completeness and accuracy of reporting of health issues (Schwartz and Woloshin, 2004, Moynihan 2003, Entwistle 1995).

The health issues that are seen to have been covered range from HIV/AIDS, Malaria, Polio, Tuberculosis, cancer, hypertension, diabetes to expert opinions and general health discourses promoting good living and the need to maintain a healthy state.

\section{HEALTHY LIFESTYLE AND MITIGATION OF DISEASES}

For reasons ranging from poverty, ignorance, tight work schedule (often resulting from the growing need for individuals to get a means of livelihood in a seemingly tough environment with tall economic demands), larger population of people find themselves making poor food choices and unhealthy habits that stand in the way of achieving a healthy state.

Bukola Adebayo, in a report published on January 16, 2013 in the Punch Newspaper writes that high blood pressure which is also a prevalent disease in Nigeria also affect the young people. In the report, the Chief Medical Director of Dayspring Hospitals, Agah, Lagos, Dr. Samuel Adebayo said: though the disease could be hereditary, the increase in young Nigerians with high blood pressure (the root cause of stroke, heart attack and diabetes), have been linked to increased intake of salt and fatty foods, obesity, lack of exercise and inadequate intake of fruits and vegetables among this generation.

Dr. Adebayo was quoted to have said, "Young people must begin to watch their diet and their lifestyle so that they do not become obese or overweight. Eating fatty and salty food is now a risky way of life; no more a luxury. Drinking alcohol and smoking is no longer going to be a trend but a danger. These are all habits that young people must run from if they want to live longer." Other experts have equally aired their advice on this subject. Thus, what seem rife in the various media platforms, including the internet and the Newspapers are expert advice on Healthy living and lifestyle which often seem to be promoting good health behavior among people.

In explaining what a healthy lifestyle entails Nancy Clarke, a health writer of the LiveStrong Foundation writes in popular online health blog, 'livestrong.com' that:

\section{a healthy lifestyle leaves you fit, energetic and at reduced risk of disease, based on the choices you make about your daily habits. Daily exercise, food nutrition and adequate sleep are the foundations for continuing good health. Managing stress in positive ways, instead of through smoking or drinking alcohol, reduces wear and tear on your body at the hormonal level (Clark 2019)}

She added that for a longer and more comfortable life, one should put together his plan for a healthy lifestyle and live up to it.

Dr. Yusuf Issa, a German-trained expert in complementary and Alternative Medicine has also attributed most chronic health problems to food intakes. According to him majority of common illnesses are caused by factors that are completely in one's control. While this belief have become so common in the midst of good number of health problems affecting us, it brings to question the level of awareness of the Nigerian public to the common 
beliefs about healthy lifestyle choices and how they can prevent or mitigate against terminal diseases when they are strictly adhered to.

Okonkwor (2005) notes, the most important choice to make is deciding whether or not to smoke as smoking remains principal cause of premature and entirely preventable deaths in most western countries. Apart from smoking, Okonkwor further explained that when it comes to a healthy lifestyle, there are two other areas of equal importance that lie within individual control - diet and exercise. This according to her, is why Newspapers discourses seem to be focusing on diet with references made to health enhancing and/or healing properties of foods, explaining why these should be included in the daily diet and for general purposes.

Thus, this is why this study sought to find out among other things, whether Nigerians are knowledgeable of the healthy lifestyle suggested in the print media as a way of preventing or mitigating these diseases.

\subsection{Disease Prevention through Diet and exercise}

There is universal agreement among nutritionists, doctors and scientists about the importance of diet in both the incidence and prevention of disease. It is also accepted that the type of diet prevalent in many Western countries is unhealthy and responsible not only for diseases that cause disability and premature death but also for an epidemic of obesity and a steep rise in the incidence of non-insulin dependent diabetes mellitus. Hales (1992), rightly observes that the food we eat can increase or decrease our risk of developing many illnesses, including the two most deadly diseases in our society - heart disease and cancer. Even as it (nutrition) is seen as "the science that explores the interactions between our bodies and the food we eat" (Hales, 1992; p. 97), it is also agreed that to maintain a healthy state, it is necessary for people to take cognisance of their dietary intakes. For instance, the body requires carbohydrates, fats, proteins, vitamins and minerals to maintain healthy organs, bones, muscles and nerves and to produce hormones and chemicals that are necessary for the proper functioning of the body organs (Melissa 2015). These foods according to experts should be taken in moderation and in accordance with the body requirements if it must work optimally. Figure 1 shows the eatwell plate which highlights the different types of food that make up our diet and shows the proportions we should eat them to have a healthy, balanced diet. As Okonkwo (2015, p. 30) rightly observes, "it is certainly better to eat some things sparingly and in moderation but, above all, food should be enjoyed. There is little point in eating a particular food, however healthy it may be, if you hate (sic) every mouthful", she said. In deciding on your daily intake of food, the "Recommended Dietary Intakes" for populations can be useful in this regard.

Even as the facts about foods are well known, many people remain confused about what they should be eating. This is partly due to barrage of sometimes conflicting advice about food which has been aimed at the public in recent years.

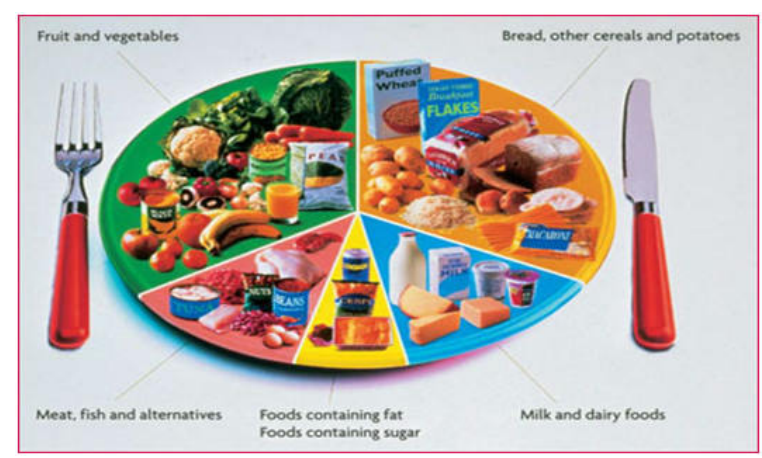

Figure 1. Eatwell plate

Exercise, which refers to bodily movement undertaken to improve or maintain one or more of the components of physical fitness, is also an important choice to make for good health. However, it is unfortunate that so few exercise; because exercise is a critical component of healthy lifestyle. In fact, according to Stein and Pruitt (1999), exercise may well be the single most important thing one can do if one wants to live a long and healthy life. Researchers have persistently found that higher levels of physical activity and physical fitness lead to longer life and a higher quality of life (Stein and Pruitt, 1999). Foremost of all the benefits of regular exercise is that it 
can reduce the risk of coronary artery disease and hypertension. It is also said to help control body weight. Exercise is known to help the heart in many ways. On how exercise does this, Stein and Pruitt write:
Exercise affects your heart in a number of ways. It increases the plasma, thus thinning the blood and allowing it to move smoothly through the vessels. It also stimulates the release of natural enzyme that prevents blood from clotting. Exercise contributes to lowering of blood pressure and reducing risk for hypertension by increasing the number and capacity of capillaries which carry the blood to arteries. Exercise improves the level of blood cholesterol by raising the "good" cholesterol, the high density lipoproteins (HDLs) and lowering the plaque-forming cholesterol, the low density lipoproteins (LDLs). It can also help lower blood sugar levels and increase the body's sensitivity to insulin (Stein and Pruitt, 1999; p. $156-$ 157).

The chief reason people give for why they do not exercise, according to the President's Council on Physical Fitness and sports, (1993), is that they do not have the time or that they lack the good health needed to do so. Similarly, the Surgeon General's report found that nearly half of American youth between the ages of twelve and twenty-one are not vigorously active on a regular basis. And about 14 percent of young people report no recent physical activity. The study also found that participation in all types of physical activity declines strikingly as age or grade in school increases.

Even while this is known, this study will throw insight into how the civil servants in south east Nigeria make healthy choice; whether they respond positively to the health advice regularly for good health. The general lifestyle choices as pointed out by the Public Health Agency of Canada (PHAC, 2011) are thus outlined below

1. Be a non smoker and avoid second hand smoke. If you smoke, get help to quit. Smoking is the major cause of Chronic Obstructive Pulmonary Disease (COPD) and lung cancer. It is also a major risk factor for heart attack and stroke. It's never too late to quit and reduce your risk.

2. Be physically active every day. Find an activity you like and get moving. Your heart is a muscle that needs regular exercise to stay healthy. Exercise will also make it easier to maintain a healthy body weight.

3. Eat healthy foods. Following a healthy, balanced diet can help you to maintain a healthy weight, lower your cholesterol and reduce your risk for disease. Choose high fibre, lower fat foods and 5-10 servings of fruit and vegetables every day.

4. Achieve a healthy weight. Being overweight increases your risk for diabetes, heart disease and some cancers. The risk of a heart attack is three times higher in women who are overweight than in those who have a healthy weight.

5. Control your blood pressure. Keeping your blood pressure in check can help prevent damage to the walls of your arteries like tears and bulges and possibly slow the hardening of your arteries. Have your blood pressure checked regularly by your healthcare provider and follow your management directions.

6. Limit your intake of alcohol. Drinking too much alcohol can put you at risk for many kinds of cancer. While there is some evidence that moderate drinking may offer some health benefits, too much alcohol is unhealthy. Moderate drinking means an average of one drink for women or two drinks for men per day.

7. Reduce your stress. Take time to relax. Stress can raise your cholesterol level and blood pressure and lead to heart attack and stroke. Stress is also a trigger for mental health problems like depression. See your healthcare provider for help in managing stress.

8. Be screened or tested regularly. Report any new signs and symptoms to your healthcare provider. It's also important to know your body and have regular check-ups to measure your blood pressure, cholesterol and blood sugar levels. In many cases the earlier a problem is detected, the easier it is to treat.

\section{NEWSPAPER READERSHIP IN NIGERIA}

By the late 1990s, the availability of news via 24 hour television channels and then the internet posed ongoing challenge to most newspapers in developed countries. Paid circulation has declined while advertising revenue which makes up the bulk of most newspapers' income has been shifting from print to the new media, resulting in a general decline in profits. Oseni and Ehis (2011 p.1) express the view that short fall in advertising revenues and reduction in circulation as a result of the ICT, signals the gradual closing down of print media in Nigeria; especially the newspaper. Johnson $(2013$, p.7) takes a similar stand that the print media is on the verge of 
extinction; that by 2030 the ICT would completely subdue the print media industry in Nigeria with people having to seek information through mobile phones.

While this seems to be the reality, some newspaper proponents are of the view that newspapers and magazines cannot be completely phased out as they will continue to survive the technological age. One way the Nigerian Newspapers is surviving this age is by launching strong online presence to tap the new media's advantage of immediacy, interactivity and convenience. Aside this, all of the detailed reports and features that apply in the print version are also uploaded online for online readers to read, thereby having their share of online users.

This may be why some newspaper proponents still believe that since radio and television did not subdue the print media completely, they cannot be subdued completely by ICT. Rather, newspapers managers can leverage on its weaknesses and consolidate on its advantages. Ani, Uchendu \& Atseye (2007 p. 362) support this view saying that no matter the breakthrough in the electronic world, the print media readership will still keep up because of some limitations of the use of ICT in Nigeria. Some of these problems include: lack of steady power supply, lack of financial capacity, inadequate knowledge of how to navigate the internet, not being computer literate, network fluctuation, and low speed of the server, among others.

Dominick (2009 p. 303) strongly believe that the new media can never make the print media to be completely redundant as the print media still remain the most credible source of information when compared to the internet.

Concerning this issue of credibility which is believed to be making newspaper more endearing to readers than internet news, Oyero (2013 p. 51) notes that one of the major reasons people still go back to traditional media is its credibility and trustworthiness adding that if social networks are not made to be more credible and trustworthy, some of its users might begin to refer back to the traditional media as a primary source of information.

However, Rajini (2011) presents an optimistic view about the growth of the newspaper readership saying that the cheaper printing and distribution, increased literacy, the growing middle class in most part of the world, as well as other factors are compensating for the emergence of the electronic media, including the internet as newspapers readership continues to grow.

Newspapers provide up-to-date information on local, state/provincial, national, and world issues. They are among the most widely-read periodicals that are available and accessible to the vast majority of people of all ages and walks of life in any community (Igbeka and Ola, 2010). Every category of reader can find some important, current, and interesting information in newspapers. Today's newspapers in Nigeria have continued to device means of making content easily accessible and friendly. Instead of allowing the advancement in technology to eat them up or drive them out of extinction, they continuously tap into this technological trend to make the printed copy not only readable but such that the content can be easily accessed by the reader. The newspaper design elements are there to make information easily accessible to the reader (Igbeka and Ola, 2010). For example, proportional placement of headlines, the simple language, the use of graphics and pictures which appear alongside important stories are largely used to make the paper accessible and easily readable by the readers.

The most current analysis and criticism of politics, economics, health, religion, sports, psychological and emotional issues, music, theatre, television, the fine arts, and even comics are covered by newspapers. Igbeka and Ola (2010) reiterate that, "newspapers are important because they carry current information and they keep the readers informed of events and happenings within and outside their immediate environments. They are useful for education, recreation, entertainment and relaxation." News is written as a way of disseminating information to a large group of people. Reporters and editors are usually conscious of the language they use in news reportage to attract popular readership.

In positioning newspapers within the news environment and establishing their academic and research viability, Cheney et al, (2006) insist that, despite the growing presence of news on the Internet, radio, television, etc., a library's current newspaper collection can continue to play a vital role in the academic community. In fact, they advocate that, in order to improve newspaper readership among college-age students, libraries should provide free and unhindered access to newspapers to all library users.

Thus, the availability of Nigerian newspapers in the Libraries of Higher institutions in Nigeria, seem to be the reason newspaper readership is there among youths. Igbeka and Ola (2010) in their study of newspaper consultations between 2000 and 2006 showed the rate of use of newspapers by students of the two faculties at the IMT campus. The record shows details of daily consultations/requests of newspapers. It establishes that the library subscribes to a number of daily papers and that students actually consult the papers. Their purpose for 
such consultations is not indicated in the records.

These findings showed that students read newspapers and they also buy them on regular basis, especially when they find it convenient. It can be suggested from the research findings that there is a strong presence of Nigerian newspaper readership group among library users which can be in secondary school, higher institutions as well as government and privately owned libraries across the country.

Nigerian newspaper is also noted to have a wider circulation in almost all government owned and private owned offices across the nation and so, a greater percentage of its readers can be found there. For example, in a study to determine newspaper readership in the civil service, Olusoji (2012) found that among civil servants in Ekiti State, newspapers were available and about $93 \%$ of the civil servants read the papers except that they don't read them often. It is equally assumed that Newspaper readership rate in the south east might be similar to that of the south west.

\section{NIGERIAN NEWSPAPER READERSHIP'S DISPOSITION TO TOPICAL COVERAGE}

It is a truism that seeking relevant and viable information through the print media is inevitable even as it is noted that information gap is the bane of technological advancement. Thus, the most likely source of information regarding food and food safety matter and healthy choices is the print media. Here, continually lies a connection between innovative creation and its usage by the target audience. It is probably for this that some researchers often find it necessary to examine media coverage of issues relating to health or any topical coverage in our daily newspapers to uncover the public understanding or perception of the issue being presented. In covering a topical issue pertaining to health or any other subject, an objective is to bring about public awareness, increase public knowledge and achieve the desired action from the target audience or readers of the message. All these are gauged through their (audience) disposition towards that coverage. Here comes the importance of framing in the coverage of issues; since how a message is framed will determine the target audience disposition towards that issue - that is, whether or not the message will be read, understood and whether or not they will respond in the way intended by the .communicator. The view of Fawole et al (2012) on this, is apt: "The way an issue is framed could provoke an element of fear in readers, resulting in some levels of uncertainty and development of extreme actions towards any contact with the concerned framed issue" (p. 12)

\section{THEORETICAL FRAMEWORK}

Just as every research work in mass communication is rooted in theory, so do the field of Health communication. Early communications relies on the assumption that giving correct information about prevention of disease will lead to behavioural change. Yet research has proven this to be inadequate even as further theoretical understandings indicate that it is not just giving the right information that change behaviour but the presence of elements that will affect audience belief and perception about the message. This study was, therefore, anchored on the Health Belief Model.

\subsection{The Health Belief Model (HBM) - An overview}

The Health Belief Model (HBM) is one of the most widely used theories in health behavioural research. It is a psychological model that attempts to explain and predict health behaviours by focusing on the attitudes and beliefs of individuals. The HBM was first developed in the 1950s by a group of social psychologists: Hochbaum, Rosenstock and Kegels, who were working in the U.S. Public Health Services. It was developed in an attempt to better understand the widespread failure of a free tuberculosis (TB) health screening program. Since then, the HBM has been adapted to explore a variety of long- and short-term health behaviours, including sexual risk behaviours and the transmission of HIV \& AIDS.

The HBM suggests that people's beliefs about health problems, perceived benefits of action and barriers to action and self efficacy explain engagement (or lack of engagement) in health promoting behaviour. It also holds that a stimulus or cue to action must also be present in order to trigger the health-promoting behaviour (Janz and Becker; 1984).

Explaining the tenets of The HBM, Adum (2011) states that the perception of a personal health behaviour threat is itself influenced by at least three factors; general health values, which include interest and concern about health; specific health beliefs about vulnerability to a particular health threat; and beliefs about the consequences of the health problem. Once an individual perceives a threat to his/her health and is simultaneously cued to action, and his/her perceived benefits outweighs the consequences of not taking action, then that individual is 
most likely to undertake the recommended preventive health action (Adum 2011, p. 40). However, there may be some variables (demographic, socio-psychological, and structural) that can influence an individual's decision (Champion, 1984).

Put explicitly, the HBM assumes that behaviour change occurs with the existence of three ideas at the same time, including perceived susceptibility and severity, perceived threat and perceived benefits and barriers. This means that an individual recognizes that there is enough reason to make a health concern relevant (perceived susceptibility and severity); that person understands he or she may be vulnerable to a disease or negative health outcome (perceived threat) and lastly the individual must realize that behaviour change can be beneficial and the benefits of that change will outweigh any costs of doing so (perceived benefits and barriers).

\subsection{HBM as a model for the study}

Bringing this model within armbit of the study on Nigerian Newspaper readership's response to discourses on healthy lifestyle for diseases prevention, there is the understanding based on this model, that for newspaper readers to respond positively to media messages on healthy lifestyle by making healthier choices, it is dependent on the idea that:

1. The readers must believe that they can come down with any of the diseases (perceived susceptibility)

2. They believe that the consequences of being affected with a disease are significant enough to try to avoid it (perceived severity)

3. They equally believe that the recommended action of adopting a healthier lifestyle would prevent the diseases from coming to them (perceived benefits)

4. They identify their personal barriers to adopting the healthy lifestyle suggested in the newspapers. This may be time constraint, busy work schedule, financial constraint. They can explore ways of avoiding these barriers perhaps by engaging in physical activity while working e.g running up the stair case or walking a trekking distance rather than wait until one gets time to go to the gym. They must see that the benefits outweigh the cost. (perceived barriers)

5. They receive reminder cues in form of repeated messages or testimony of persons that have adopted the health behaviour being promoted (cues to action)

6. The readers then develop some level of confidence in their ability to apply health behaviour promoted in the media.

\section{METHOD}

To achieve our study's objectives and to answer the research questions, we adopted the triangulation approach. Thus, Content Analysis and the survey methods were employed.

Survey, one of the methods, was considered appropriate for the study because the work sought to reveal how Nigerian newspaper readership responds to discourses in the Newspapers on healthy lifestyle for prevention of diseases. Ohaja (2005) makes the point that whenever the source of primary data for a study would be necessary, the views of members of the public or any particular group, a survey method of research will be required. Thus, the survey method enables the researcher to empirically determine the readership's exposure to Newspaper discourses and gauge the respondents' knowledge and disposition towards the subject under investigation.

Content Analysis was also used in order to achieve one of the research objectives that sought to determine the presence and extent of discourses on healthy lifestyle for prevention of diseases published in the Nigerian Newspapers.

For the content Analysis, the population comprised all the national newspapers in Nigeria. The entire Nigerian Newspapers constitute the population in this study because the issue of discussion is on a national scale.

Similarly for the Survey method, all the state Civil Servants working in the state secretariats in the Southeast, totaling about 46, 573, theoretically make up the population for this study. They include the State Secretariat, Enugu, State Secretariat Umuahia, State Secreteriat Abakiliki, State Secreteriat Awka and State Secreteriat, Owerri. However, as three state secreteriats - Awka, Owerri and Umuahia had been randomly selected for the study, the working population was 30, 282 making up the entire state civil servants from the selected secretariats. This statistics was obtained from the Head of Service in the various states.

All the National Newspapers in Nigeria constitute the population for the study. A purposive selection was then carried out to obtain a working population of the Newspapers. Thus, the working population is the top 10 selling 
national Newspapers according to ADVAN's survey 2010.

However, four national newspapers - The Nation, Sun, Vanguard and the Guardian were randomly selected from the top National Newspapers that have wide circulation. The results from the selected Newspapers can be generalized to the entire population because they are national newspapers.

The Newspapers' discourses on healthy lifestyle for prevention of illnesses in the third quarter of the year, 2018 (July to September) were examined. The third quarter of the year was purposively chosen for recency as the months fell within the period this study was carried out. The editions that were selected for the study were also chosen based on the actual days in which the newspapers publish segment on health and healthy living related discourses. Thus, two days in each week were chosen for each of the newspapers. In all, a total of 118 editions were selected for the study.

A study sample of 395 was drawn from the population of study. This sample size had been determined for this study by looking at the different sample sizes worked out by Meyer (1975) for populations ranging from 1000 to infinity at 95 per cent confidence level as well as using Taro Yamane's formula for determining sample size.

The sample frame for the working universe is shown in the state civil servants distribution in Table 2.

Table 1. State secretariats covered by the study

\begin{tabular}{|c|c|c|c|}
\hline S/N & State & Location of State Secreteriat & Population of Civil Servants \\
\hline 1. & Anambra & Awka & 13,773 \\
\hline 2. & Imo & Owerri & 8,008 \\
\hline 3. & Abia & Umuahia & 8,501 \\
\hline & Total & & 30,282 \\
\hline
\end{tabular}

A multi staged sampling was used to select the respondents from the selected secretariats. After the random selection of the states, the next stage involved the selection of Ministries. For Anambra, the Ministry of health and the Ministry of works were selected while the Ministry Of Housing and Urban Development and Ministry of Education were selected for Imo State. For Abia, Ministry of Public Utilities and the Ministry of Commerce and Industry were randomly selected for the study.

The next stage involved the selection of units from the ministries and copies of the questionnaire were given based on civil servants who were available at the time of administering the questionnaire.

For the Content Analysis, the data collection instrument was the coding sheet. This is used to transform raw data into standardized form suitable for analysis. Thus, for this study, the unit of analysis was features. Feature here refers to any article (which is not straight news or interview) in the edition under study promoting healthy choices about daily habits which involve good nutrition, daily exercise, adequate sleep, reduced alcohol intake, among others.

Cooper and Schindler (2001, p. 430) refer to the categories as keywords and referential units. For this study, the extent to which Nigerian newspapers discuss healthy lifestyle for disease prevention is measured using the following content categories:

1. Area Covered: These are the lifestyle choices that were covered in the Newspapers under study.

01 Physical Activity: This involves discourses promoting exercise and fitness

02 Food and Nutrition: Articles on balanced diet, containing nutritional and health benefits of foods, advices on the right food choices to make for good health.

03 Pro-health Behaviour: Articles promoting behaviours that are good for health such as regular screening and testing, avoiding smoking or secondary smoking, reducing intake of alcohol, personal and environmental hygiene, avoiding stress and anxiety, relaxation and sleep, maintaining healthy weight.

04 Combination: articles that have a combination of two or more of the areas in the category.

2. Depth of Coverage which include: 
01 Indepth: a discourse written by an expert or being quoted in the article; an article offering full information and supporting facts.

02 Shallow coverage: Providing less information; not written by an expert and nor quoted in the article

3. Length of Published Material: This, in terms of the number of words in the article

$010-250$ words

$02 \quad 251-500$ words

$03501-750$ words

$04751-1000$ words

051000 words and above

4. Health Issue Discussed

01 Cancer

02 Cardiovascular disease

03 Diabetes

04 Combined

05 General Health

5. Size of Published Material

01 Full page and more

02 Half page

03 Quarter page

04 Less than Quarter page

6. Pictures

01 Picture(s) attached

02 No picture(s) attached

For the survey method, a 36-item pre-coded questionnaire was used as the data collection instrument. These items addressed the variables that are related to the research questions. The first three questions $(1-3)$ sought the respondents' demographic data. These included, gender, age and qualification. Questions $4-12$ sought to establish the respondents' exposure to Newspapers discourses on healthy lifestyle. The third set of questions, (13 - 19) sought to find out who among the respondents was knowledgeable of the safe habits necessary for the prevention of diseases. Questions $20-27$ sought to find out the readers' disposition towards newspapers discourses on healthy lifestyle while the last set of questions $(28-36)$ was to establish whether they take health action as suggested in the newspaper health discourses.

The measurable variables for this research included the independent and dependent variables.

The independent or socio-economic-status (SES) variables included, gender, age and respondent's highest educational qualification. These were measured by simply asking questions that sought demographic data.

Some of the dependent variables measured included, Newspapers discussions of healthy lifestyle; exposure to newspapers discourses on healthy lifestyle; knowledge of safe habits necessary for prevention of chronic diseases; disposition towards health advice in the newspapers; taking health action as suggested in the newspapers.

Newspapers discussions of healthy lifestyle: This was measured using content analysis to find out the extent to which healthy lifestyle issues are discussed in the Nigerian newspapers. Coding parameters such as the area covered, depth of coverage, length of published material and size of published material were used to measure this variable.

Exposure to newspapers discourses on healthy lifestyle: this was measured by asking the respondents questions on whether they have read healthy living advice as mentioned in the questions.

Knowledge of safe habits necessary for prevention of chronic diseases: to measure this variable, the respondents were asked to indicate their agreement to a set of statement or information on healthy choices and diseases

Disposition towards health advice in the newspapers: this was measured by asking the respondents a set of questions relating to their disposition towards the healthy living advice they read in the newspapers.

Taking health action as suggested in the newspapers: a set of questions relating to the health actions were asked the respondents.

The data for the content analysis was collected in one week. There was no need for inter coder reliability since the investigation was carried out by the researchers after each coding categories was exclusively and extensively 
defined and understood before collecting the data. Survey data was collected in two weeks. The researchers employed the use of research assistants to collect data from Owerri and Umuahia while that of Awka was collected by the researchers.

\section{DATA ANALYSIS AND INTERPRETATION}

For the survey, a total of 395 copies of the questionnaire were distributed - 132 copies each for Anambra and Umuahia secretariats while Imo State secretariat got 131 copies because it is the state with the list population of civil servants among the states selected in South eastern Nigeria. Out of 132 copies of the questionnaire distributed to state civil servants at Umuahia, 129 were returned and 3 were lost. At the Imo State Secreteriat, 126 copies were returned and 5 were lost. Then, at the State Secretariat in Awka, 131 copies were returned while one was lost.

The total number of copies of the questionnaire returned $(\mathrm{N}=386)$ represents 97 percent of the sample of 395 respondents. However, against the backdrop of Myer's sample of 370, this response rate had been considered appreciable enough to provide the necessary data for this study; hence its use.

\subsection{Healthy Lifestyle Discourses in Nigerian Newspapers}

Research Question one sought to establish the extent to which Nigerian Newspapers discuss healthy lifestyle for prevention of diseases. Accordingly, a content Analytical study was carried out using four Nigerian Newspapers - Guardian, Sun, Nation and Vanguard to test for the presence, frequency and extent of discourse. The content categories used to measure this variable include: area of lifestyle or choice mentioned in the discourse, the depth of the discourse, the length of the published item, the health issue discussed as well as the size of published materials. One hundred and twenty (120) stories from the 118 selected editions of the four newspapers over a three-month period were analyzed. Below are the results that were obtained.

Table 2: Healthy lifestyle discourses in Nigerian newspapers

\begin{tabular}{|c|c|c|c|c|c|}
\hline \multicolumn{6}{|c|}{ Total number of discourses per paper } \\
\hline \multicolumn{2}{|l|}{ Newspaper } & \multicolumn{4}{|c|}{ Frequency (Percent) } \\
\hline \multicolumn{2}{|l|}{ Guardian } & \multicolumn{4}{|l|}{$39(33 \%)$} \\
\hline \multicolumn{2}{|l|}{ Sun } & \multicolumn{4}{|l|}{$35(29 \%)$} \\
\hline \multicolumn{2}{|l|}{ Vanguard } & \multicolumn{4}{|l|}{$30(25 \%)$} \\
\hline \multicolumn{2}{|l|}{ The Nation } & \multicolumn{4}{|l|}{$16(13 \%)$} \\
\hline \multicolumn{2}{|l|}{ Total } & \multicolumn{4}{|l|}{$120(100 \%)$} \\
\hline \multicolumn{6}{|c|}{ Frequency of report per Newspaper in each month } \\
\hline & Guardian & Sun & Vanguard & Nation & $\begin{array}{l}\text { Combined } \\
\text { Total }\end{array}$ \\
\hline Month & Frequency & Frequency & Frequency & Frequency & Frequency \\
\hline July & $14(36 \%)$ & $12(34 \%)$ & $12(40 \%)$ & $6(37 \%)$ & $44(37 \%)$ \\
\hline August & $11(28 \%)$ & $15(43 \%)$ & $12(40 \%)$ & $3(19 \%)$ & $41(34 \%)$ \\
\hline September & $14(36 \%)$ & $8(22 \%)$ & $6(20 \%)$ & $7(44 \%)$ & $35(29 \%)$ \\
\hline Total & $39(100 \%)$ & $35(100 \%)$ & $30(100 \%)$ & $16(100 \%)$ & $120(100 \%)$ \\
\hline
\end{tabular}

Table 2 shows the frequency of discourses on healthy lifestyle as published in each of the Newspapers. From the table above, it is revealed that 120 discourses were found in the Newspapers studied. Out of this figure, Guardian had 39 reports representing 33\%, Sun 35 representing 29\%, Vanguard, 30 representing 25\% while the Nation had 16 reports which represents $13 \%$. Therefore, out of the newspapers studied, Guardian had more of the discourses on healthy lifestyle, followed by Sun, then Vanguard and lastly The Nation Newspapers. This could be a matter of editorial policy which makes the papers maintain some important segment of their content. It was observed 
that while all the papers have days devoted for this important health segment, not all the papers studied stuck to the days and number of pages allotted for health and other related discourses.

Similarly, Table 2 shows that the month of July had highest number of published discourses (44 representing $37 \%$ ), from the combined analysis. August was slightly lower with 41 reports representing $34 \%$ while September had 35 stories representing $29 \%$.

Table 3: Healthy choices covered in the newspapers

\begin{tabular}{|l|l|l|l|l|l|}
\hline & Guardian & Sun & Vanguard & Nation & Combined Total \\
\hline $\begin{array}{l}\text { Healthy Choice } \\
\text { Discussed }\end{array}$ & Frequency & Frequency & Frequency & Frequency & Frequency \\
\hline $\begin{array}{l}\text { Physical } \\
\text { Activity }\end{array}$ & $10(26 \%)$ & - & $13(43 \%)$ & $1(6 \%)$ & $24(20 \%)$ \\
\hline $\begin{array}{l}\text { Healthy food, } \\
\text { diet } \\
\text { nutrition }\end{array}$ & $20(51 \%)$ & $22(63 \%)$ & $12(40 \%)$ & $11(69 \%)$ & $65(54 \%)$ \\
\hline $\begin{array}{l}\text { Pro-health } \\
\text { behaviour }\end{array}$ & $8(20 \%)$ & $6(20 \%)$ & $4(13 \%)$ & $1(6 \%)$ & $20(17 \%)$ \\
\hline $\begin{array}{l}\text { Combination of } \\
\text { choices }\end{array}$ & $1(3 \%)$ & $35(100 \%)$ & $30(100 \%)$ & $16(100 \%)$ & $120(100 \%)$ \\
\hline Total & $39(100 \%)$ & $1(3 \%)$ & $3(19 \%)$ & $11(9 \%)$ \\
\hline
\end{tabular}

The above table shows the healthy choices that were discussed in the newspapers. The combined analysis shows that 65 stories representing 54\% were discourses on healthy food, diet and nutrition while physical activity like exercise got 24 reports representing $20 \%$. This is followed by pro health behaviours like avoiding smoking, hygiene; sleep, stress reduction etc are 20 which represent $17 \%$; then, discourses that more than one of the choices in the category are just 11 , representing $9 \%$. This suggests that most of the healthy lifestyle discourses in Nigerian newspapers are centered on healthy eating, food, diet and nutrition.

Table 4: Depth of healthy lifestyle discourses in the newspapers

\begin{tabular}{|l|l|l|l|l|l|}
\hline & Guardian & Sun & Vanguard & Nation & Combined Total \\
\hline Depth & Frequency & Frequency & Frequency & Frequency & Frequency \\
\hline In-depth & $19(49 \%)$ & $27(77 \%)$ & $20(67 \%)$ & $11(69 \%)$ & $77(64 \%)$ \\
\hline Shallow & $20(51 \%)$ & $8(23 \%)$ & $10(33 \%)$ & $5(31 \%)$ & $43(36 \%)$ \\
\hline Total & $39(100 \%)$ & $35(100 \%)$ & $30(100 \%)$ & $16(100 \%)$ & $120(100 \%)$ \\
\hline
\end{tabular}

The depth of discourse was measured by checking whether or not reports were written by expert in the area of discourse; have experts' views and opinion on the issues and/or contain additional facts and information. From the table, majority of the discourses in the Newspapers (77 representing 64\% ) were in-depth while 43 representing $36 \%$ were considered shallow. 
Table 5: Length of published material

\begin{tabular}{|l|l|l|l|l|l|}
\hline & Guardian & Sun & Vanguard & Nation & Combined Total \\
\hline Length (words) & Frequency & Frequency & Frequency & Frequency & Frequency \\
\hline $0-250$ & $10(26 \%)$ & $1(3 \%)$ & $3(10 \%)$ & - & $14(12 \%)$ \\
\hline $251-500$ & $14(36 \%)$ & $8(22.5 \%)$ & $9(30 \%)$ & $3(19 \%)$ & $34(28 \%)$ \\
\hline $501-750$ & $8(20 \%)$ & $9(26 \%)$ & $12(40 \%)$ & $8(50 \%)$ & $37(31 \%)$ \\
\hline $751-1000$ & $3(8 \%)$ & $8(22.5 \%)$ & $5(17 \%)$ & $3(19 \%)$ & $19(16 \%)$ \\
\hline 1001 and above & $4(10 \%)$ & $9(26 \%)$ & $1(3 \%)$ & $2(12 \%)$ & $16(13 \%)$ \\
\hline Total & $39(100 \%)$ & $35(100 \%)$ & $30(100 \%)$ & $16(100 \%)$ & $120(100 \%)$ \\
\hline
\end{tabular}

The length in terms of the number of words contained in each of the discourses was measured. Table 5 shows that 37 respondents representing 31\% have words between $501-750 ; 34$ (28\%) reports fall within the range of 251 - 500 words; then, 19 (16\%) 751 -1000 words. Sixteen reports representing 13\% fall within the range of 1001 words and above. Lastly, 14 reports representing $12 \%$ fall within $0-250$ words. This means that most of the discourses in the Newspapers on healthy living fall between $501-750$ words; they are not too short, neither are they too long in length.

Table 6: Health issue discussed in the newspapers

\begin{tabular}{|l|l|l|l|l|l|}
\hline & Guardian & Sun & Vanguard & Nation & Combined Total \\
\hline Health Issue & Frequency & Frequency & Frequency & Frequency & Frequency \\
\hline Cancer & $3(8 \%)$ & $4(11 \%)$ & $4(13 \%)$ & $2(13 \%)$ & $13(11 \%)$ \\
\hline Heart Disease & $5(13 \%)$ & $12(34 \%)$ & $6(20 \%)$ & $2(13 \%)$ & $25(21 \%)$ \\
\hline Diabetes & $4(10 \%)$ & $2(6 \%)$ & - & $1(6 \%)$ & $7(6 \%)$ \\
\hline Combination & $3(8 \%)$ & $1(3 \%)$ & $6(20 \%)$ & - & $10(8 \%)$ \\
\hline General Health & $24(61 \%)$ & $16(46 \%)$ & $14(47 \%)$ & $11(68 \%)$ & $65(54 \%)$ \\
\hline Total & $39(100 \%)$ & $35(100 \%)$ & $30(100 \%)$ & $16(100 \%)$ & $120(100 \%)$ \\
\hline
\end{tabular}

Table 6 shows the health issues (disease) that are the center of discourses for each of the reports in the Newspapers. Details show that cancer has $13(11 \%)$ reports, Heart disease 25 (21\%), Diabetes 7 (6\%). A combination of two or more of the illnesses has $10(8 \%)$ while general health reports constitute $65(54 \%)$. This indicates that most of the healthy lifestyle discourses in Nigerian Newspapers centre on general health and well being of individuals rather than on specific illness. A discourse where an illness is specified, then it is heart disease or cancer.

Table 7: Size of published material

\begin{tabular}{|l|l|l|l|l|l|}
\hline & Guardian & Sun & Vanguard & Nation & Combined Total \\
\hline Size & Frequency & Frequency & Frequency & Frequency & Frequency \\
\hline $\begin{array}{l}\text { Full Page and } \\
\text { more }\end{array}$ & $14(36 \%)$ & $12(34 \%)$ & $21(70 \%)$ & $2(12 \%)$ & $49(41 \%)$ \\
\hline Half page & $14(36 \%)$ & $19(54 \%)$ & $9(30 \%)$ & $11(69 \%)$ & $53(44 \%)$ \\
\hline Quarter Page & $9(23 \%)$ & $3(9 \%)$ & - & $1(6 \%)$ & $13(11 \%)$ \\
\hline $\begin{array}{l}\text { Less than } \\
\text { quarter Page }\end{array}$ & $2(5 \%)$ & $1(3 \%)$ & - & $2(13 \%)$ & $5(4 \%)$ \\
\hline Total & $39(100 \%)$ & $35(100 \%)$ & $30(100 \%)$ & $16(100 \%)$ & $120(100 \%)$ \\
\hline
\end{tabular}


Table 7 shows that majority of the stories were given half page 53 (44\%). Many of the stories 49 (41\%) were given full page and above. Thirteen stories, representing $11 \%$ were given quarter page while just a few, 5 representing $4 \%$ were given less than quarter page. This result means that most of the healthy lifestyle discourses in Nigerian Newspapers were given half page and more.

Table 8: Discourses published with pictures

\begin{tabular}{|l|l|l|l|l|l|}
\hline & Guardian & Sun & Vanguard & Nation & Combined Total \\
\hline Variable & Frequency & Frequency & Frequency & Frequency & Frequency \\
\hline $\begin{array}{l}\text { Pictures } \\
\text { attached }\end{array}$ & $28(72 \%)$ & $29(57 \%)$ & $29(97 \%)$ & $10(62 \%)$ & $87(73 \%)$ \\
\hline $\begin{array}{l}\text { No pictures } \\
\text { attached }\end{array}$ & $11(28 \%)$ & $15(43 \%)$ & $1(3 \%)$ & $6(38 \%)$ & $33(27 \%)$ \\
\hline Total & $39(100 \%)$ & $35(100 \%)$ & $30(100 \%)$ & $16(100 \%)$ & $120(100 \%)$ \\
\hline
\end{tabular}

A combined analysis of the discourses published with pictures as shown in the table above, reveals that majority of the Newspaper discourses on healthy lifestyle were published with pictures attached. They represent $73 \%$ while the discourses with no pictures represent $27 \%$. This is perhaps due to the nature of discourse.

\subsection{Exposure to Newspaper Discourses on Healthy Lifestyle for disease prevention.}

The primary goal here was to determine who among the respondents are exposed to Newspaper discourses on healthy lifestyle for disease prevention. First, questions were asked to know who among the respondents read newspapers and the source they rely on for information on healthy living. Thereafter, direct questions $(7-10)$ to determine exposure were asked respondents to determine whether or not they have read Newspaper articles on the subject matter. The responses were then scored to determine the level of exposure. Below is the chart on Newspaper readership among respondents.

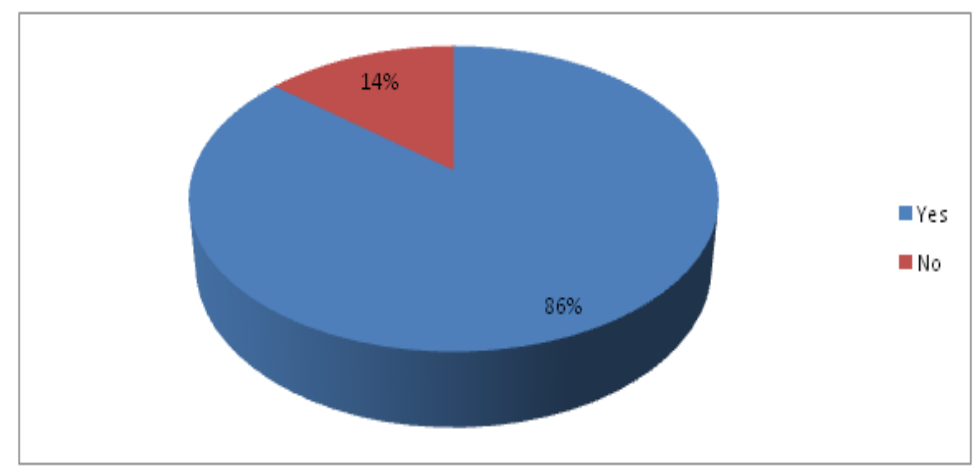

Figure 2. Respondents who read newspapers

In Figure 2, results show that majority of the respondents $(\mathrm{N}=332)$ representing $86 \%$ said they read Newspapers while $14 \%(\mathrm{~N}=54)$ say they didn't read Newspapers. This suggests that majority of the civil servants in South eastern Nigeria that we studied claimed that they read Newspapers. This validates the assumption at the beginning of this work that Civil servants might have access to Newspapers, as they either join the free readers association or it is made available to them in the office. 
Table 9. How frequent respondents read newspapers

\begin{tabular}{|l|l|}
\hline Variable & Percentage \\
\hline Regularly & $34 \%$ \\
\hline Occasionally & $53 \%$ \\
\hline Don't Know & $13 \%$ \\
\hline Total & $100 \%(\mathrm{~N}=382)$ \\
\hline
\end{tabular}

On how frequently respondents read Newspapers, the data in Table 9 shows that majority of the respondents, representing 53\% $(\mathrm{N}=203)$ read newspapers occasionally while $34 \%(\mathrm{~N}=130)$ indicated that they read newspapers regularly; $13 \%(\mathrm{~N}=49)$ of the respondents do not know how often they read newspapers. Relating this finding to the previous finding in figure 4, it can be said that although civil servants in the South East read newspapers, they did not read them on a regular basis.

Table 10. Respondents' main sources of information on healthy living

\begin{tabular}{|l|l|}
\hline Source of Information & Percentage \\
\hline Family and Friends & $27 \%$ \\
\hline Medical Personnel & $37 \%$ \\
\hline Church & $2 \%$ \\
\hline Mass Media & $34 \%$ \\
\hline & $100 \%$ \\
Total & $(\mathrm{N}=382)$ \\
\hline
\end{tabular}

Details of the data in Table 10 show that $37 \%(\mathrm{~N}=140)$ indicated medical personnel as their main source of information on healthy living. This is followed by respondents who indicated mass media as their main source of information on healthy living, representing $34 \%(\mathrm{~N}=132)$. Family and friends were also said to be a source of information by $27(\mathrm{~N}=102)$ of the respondents while the church as a source was far behind with mere $2 \%(\mathrm{~N}=$ 8). This suggests that although people rely of medical personnel for health related information e.g healthy living, they still use the mass media for information on the subject matter.

Table 11. Respondents exposure to newspaper discourses on healthy lifestyle

\begin{tabular}{|l|c|c|c|c|}
\hline Variable & $\begin{array}{c}\text { Read Newspaper } \\
\text { article on healthy } \\
\text { eating and diet }\end{array}$ & $\begin{array}{c}\text { Read } \\
\text { Newspaper articles } \\
\text { promoting active } \\
\text { life }\end{array}$ & $\begin{array}{c}\text { Read } \\
\text { Newspaper } \\
\text { articles } \\
\text { Promoting } \\
\text { good } \\
\text { health behaviours }\end{array}$ & $\begin{array}{c}\text { Read Newspaper } \\
\text { articles on regular } \\
\text { screening and } \\
\text { testing }\end{array}$ \\
\hline Yes & $90 \%$ & $90 \%$ & $88 \%$ & $82 \%$ \\
\hline No & $10 \%$ & $10 \%$ & $12 \%$ & $18 \%$ \\
\hline Total & $100 \%$ & $100 \%$ & $100 \%$ & $100 \%$ \\
& $(\mathrm{~N}=377)$ & $(\mathrm{N}=381)$ & $(\mathrm{N}=378)$ & $(\mathrm{N}=381)$ \\
\hline
\end{tabular}

The analysis in Table 12 shows that majority of the respondents are exposed to newspaper discourses on healthy 
lifestyle. The data show a near consistency of responses that is an indication of a high exposure to the discourses. The chart is shown below.

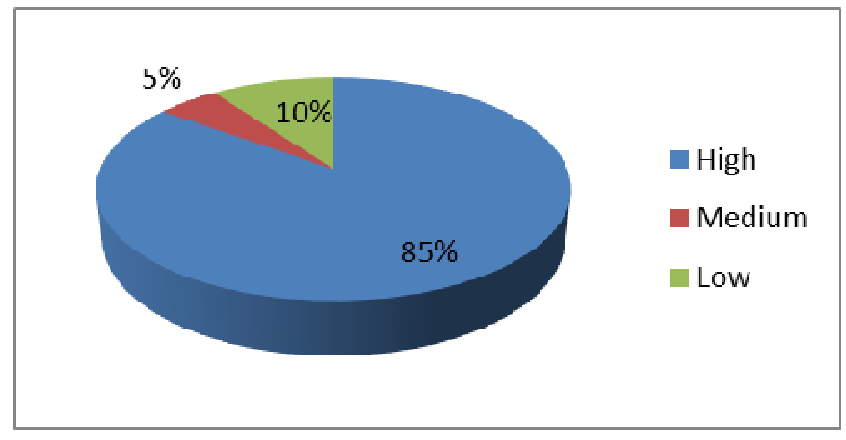

Figure 3. Respondents' level of exposure

As it can be readily observed, a large percentage of the respondents, $85 \%(\mathrm{~N}=327)$ have high exposure to newspaper discourses on healthy living for diseases prevention. Only $10 \%(\mathrm{~N}=40)$ have low exposure; while $5 \%(\mathrm{~N}=19)$ have medium exposure.

\subsection{Knowledge of Safe Habits Necessary to maintain a healthy state}

Survey data were sought on the knowledge of the safe behaviours for good health among the respondents. This was meant to help demonstrate if there was a consistent link between knowledge and exposure to Newspaper discourses on healthy lifestyle for disease prevention. Respondents' knowledge on the subject matter was determined by asking the respondents a series of knowledge questions to which they were expected to acknowledge "True" or "False". If the respondents were truly exposed to the different discourses bothering on healthy lifestyle, it would be expected that a majority of them would be able to answer in the affirmative. The data generated, as well as the scoring of the level of respondents' knowledge are presented.

Table 12. Respondents' knowledge of the safe habits necessary to maintain a healthy state

\begin{tabular}{|c|c|c|c|c|c|c|c|}
\hline Variable & $\begin{array}{l}\text { Healthy } \\
\text { food } \\
\text { choices } \\
\text { like } \\
\text { reducing } \\
\text { fat, salt, } \\
\text { sugar } \\
\text { intake } \\
\text { prevent } \\
\text { risk of } \\
\text { chronic } \\
\text { illnesses }\end{array}$ & $\begin{array}{l}\text { Regular } \\
\text { exercise } \\
\text { prevents } \\
\text { weight } \\
\text { gain that } \\
\text { increase } \\
\text { the risk of } \\
\text { diseases }\end{array}$ & $\begin{array}{l}\text { Avoiding } \\
\text { Smoking } \\
\text { and } \\
\text { reducing } \\
\text { alcohol } \\
\text { intake can } \\
\text { prevent } \\
\text { cancer, } \\
\text { heart } \\
\text { diseases } \\
\text { etc. }\end{array}$ & $\begin{array}{l}\text { Drinking } \\
\text { enough } \\
\text { water daily } \\
\text { can help } \\
\text { keep the } \\
\text { system for } \\
\text { optimum } \\
\text { performance }\end{array}$ & $\begin{array}{l}\text { Stress } \\
\text { control, } \\
\text { relaxation, } \\
\text { adequate } \\
\text { sleep can } \\
\text { control } \\
\text { cholesterol } \\
\text { level and } \\
\text { blood } \\
\text { pressure }\end{array}$ & $\begin{array}{l}\text { Being } \\
\text { overweight } \\
\text { increases } \\
\text { ones risk } \\
\text { for heart } \\
\text { diseases, } \\
\text { diabetes } \\
\text { and cancer }\end{array}$ & $\begin{array}{l}\text { Regular } \\
\text { screening } \\
\text { and testing } \\
\text { are } \\
\text { important } \\
\text { for } \\
\text { prevention } \\
\text { and } \\
\text { detection } \\
\text { of chronic } \\
\text { illnesses. }\end{array}$ \\
\hline True & $96 \%$ & $95 \%$ & $93 \%$ & $90 \%$ & $91 \%$ & $88 \%$ & $91 \%$ \\
\hline False & $14 \%$ & $5 \%$ & $7 \%$ & $10 \%$ & $9 \%$ & $12 \%$ & $9 \%$ \\
\hline Total & $\begin{array}{l}100 \% \\
(\mathrm{~N}=377)\end{array}$ & $\begin{array}{l}100 \% \\
(\mathrm{~N}=376)\end{array}$ & $\begin{array}{l}100 \% \\
(\mathrm{~N}=376)\end{array}$ & $\begin{array}{l}100 \% \\
(\mathrm{~N}=376)\end{array}$ & $\begin{array}{l}100 \% \\
(\mathrm{~N}=368)\end{array}$ & $\begin{array}{l}100 \% \\
(\mathrm{~N}=372)\end{array}$ & $\begin{array}{l}100 \% \\
(\mathrm{~N}=363)\end{array}$ \\
\hline
\end{tabular}

From the data in Table 12, a large percentage of the respondents are knowledgeable about the safe habits necessary for the prevention of diseases. Ninety-six percent $(\mathrm{N}=363)$ of the respondents knew that making healthy food choices and eating balanced diet can help prevent diseases while $14 \%(\mathrm{~N}=14)$ did not know. Ninety-five percent $(\mathrm{N}=357)$ knew that regular exercise prevents weight gain that increases the risk of diseases 
while $5 \%(\mathrm{~N}=11)$ did not know. Another 93\% (N=350) know that avoiding smoking and limiting alcohol intake can also prevent cancer and heart diseases while $7 \%(\mathrm{~N}=26)$ of the respondents did not know; $90 \%(\mathrm{~N}=339)$ also know that drinking enough water can help the body perform optimally while $10 \%(\mathrm{~N}=37)$ did not know.

Again, 91\% (N=334) know that Stress control, relaxation, adequate sleep can control cholesterol level and blood pressure while $9 \%(\mathrm{~N}=34)$ did not know. Eighty-eight percent $(\mathrm{N}=328)$ also know that being overweight increases ones risk for heart diseases, diabetes and cancer while $12 \%(\mathrm{~N}=44)$ did not know. Ninety-one $(\mathrm{N}=329)$ of the respondents also affirmed that regular screening and check up allows for early detection and prevention of diseases while 34 respondents, representing nine percent did not know.

There appears to be a common pattern between the results here and earlier findings on respondents' exposure to newspaper discourses on healthy lifestyle for disease prevention. It suggests that if they are highly exposed to these discourses, the tendency that they will be highly knowledgeable of the safe habits often discussed in the newspapers.
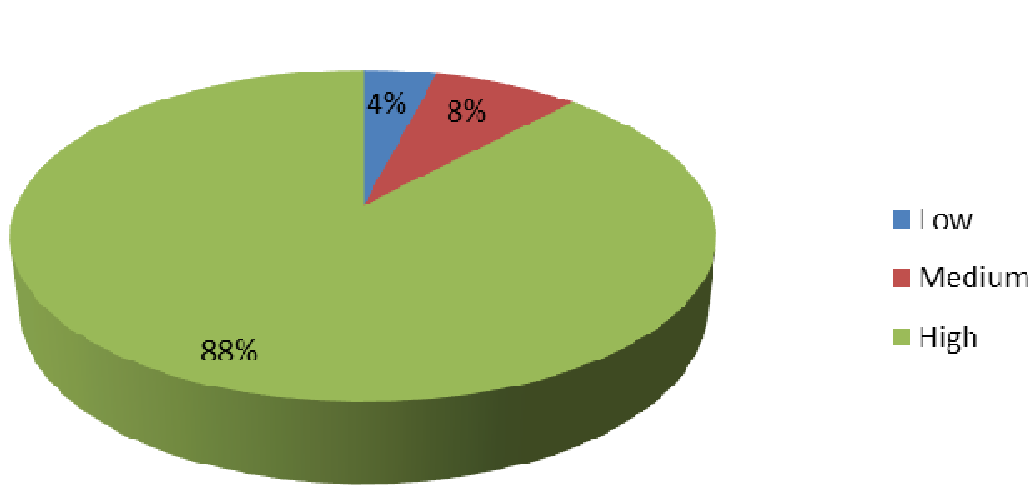

Figure 4. Respondents level of knowledge of the safe habits necessary to maintain a healthy state

As shown in Figure 4, a majority of the respondents $(88 \% \mathrm{~N}=338)$ demonstrated a high knowledge about lifestyle choices that are necessary to prevent diseases and maintain a healthy state. This is because they scored high on the measuring index which placed correct answers from 5-7 as 'high', 3-4 as medium and 0-2 as low score. Eight percent $(\mathrm{N}=29)$ showed moderate knowledge while only $4 \%(\mathrm{~N}=15)$ demonstrated a low knowledge of the safe choices for good health.

\subsection{Disposition towards Health Discourses in the Nigerian Newspapers}

The main goal of this study was to know the responses of Newspaper readers to discourses on healthy lifestyle for disease prevention; given the assumption that how a person reacts or respond to a particular message might be depended on the person's inclination, perception and tendency or readiness to act. To determine the respondents' disposition towards the health discourses in Nigerian Newspapers, a series of questions were asked to measure this. Thus, questions were asked respondents on their perception of accuracy of health advice in the papers, their perceived importance and usefulness of healthy lifestyle discourses in Nigerian Newspapers, what they consider to be responsible for their overall state of health, respondents' perception of health advices and health consciousness of respondents. The results are shown below.

Table 13. Respondents' perception of accuracy of newspaper health advices

\begin{tabular}{|l|l|}
\hline Variable & Percentage \\
\hline None is accurate & $8 \%$ \\
\hline Not all are accurate & $37 \%$ \\
\hline All are accurate & $55 \%$ \\
\hline Total & $100 \%(\mathrm{~N}=373)$ \\
\hline
\end{tabular}


Data in Table 13 reveal the perception of respondents to Newspaper discourses on healthy lifestyle for disease prevention, in terms of accuracy of discourse. The results show that 55 percent $(\mathrm{N}=205)$ think all the healthy lifestyle discourses they have read in the newspapers were accurate. The next group of respondents (37 percent $(\mathrm{N}=140)$ think not all the discourses were accurate while only 8 percent $(\mathrm{N}=28)$ believe none was true or accurate. Although, this finding reveals that majority of respondents think the discourses they read in the Newspapers are accurate, a significant number seem to be sceptical about the accuracy of the discourses.

Table 14. Respondents' perception of importance of newspaper health advices

\begin{tabular}{|l|l|}
\hline Variable & Percentage \\
\hline Very Important & $84 \%$ \\
\hline Less Important & $13 \%$ \\
\hline Not Important & $3 \%$ \\
\hline Total & $100 \%$ \\
& $(\mathrm{~N}=377)$ \\
\hline
\end{tabular}

In Table 14, data show that 84 per cent $(\mathrm{N}=316)$ of the respondents perceive the healthy lifestyle discourses as important to their overall well being. Thirteen percent $(\mathrm{N}=48)$ see the discourses as less important while just three percent of the respondents $(\mathrm{N}=13)$ say they are not important. This suggests that the civil servants in south east Nigeria see the healthy lifestyle discourses in the Newspapers as important for their overall well being.

Table 15. Respondents' perception of the usefulness of healthy lifestyle discourses in Nigerian newspapers

\begin{tabular}{|l|l|}
\hline Variable & Percentage \\
\hline Useful & $47 \%$ \\
\hline Very Useful & $51 \%$ \\
\hline Not Useful & $2 \%$ \\
\hline Total & $100 \%$ \\
& $(\mathrm{~N}=363)$ \\
\hline
\end{tabular}

Similarly, on the respondents' perceived usefulness of the healthy lifestyle discourses in the newspapers, 47 percent $(\mathrm{N}=172)$ adjudged them useful, 51 percent $(\mathrm{N}=184)$ believe they are very useful while merely 2 percent $(\mathrm{N}=7)$ claim they are not useful. Relating this to the above data, it could be seen that the respondents' perception of the health discourses are consistent as they are adjudged both useful and important.

Table 16. What respondents consider responsible for their overall state of health

\begin{tabular}{|l|l|}
\hline Variable & Percentage \\
\hline Lifestyle & $64 \%$ \\
\hline A matter of Luck & $13 \%$ \\
\hline Supernatural work & $23 \%$ \\
\hline Total & $100 \%$ \\
& $(\mathrm{~N}=365)$ \\
\hline
\end{tabular}

Table 16 reveals what respondents think is responsible for their overall state of health. Details show that 64 percent $(\mathrm{N}=235)$ believe it's the lifestyle choices they make. Twenty three percent $(\mathrm{N}=83)$ think their state of health is dependent on supernatural powers while thirteen percent $(\mathrm{N}=47)$ think their state of health is determined by luck or fate. 
Table 17. Respondents on recommended health routine

\begin{tabular}{|l|l|}
\hline Variable & Percentage \\
\hline Yes & $34 \%$ \\
\hline No & $66 \%$ \\
\hline Total & $100 \%$ \\
& $(\mathrm{~N}=368)$ \\
\hline
\end{tabular}

Data in Table 17 show the distribution of respondents that were placed by an expert on specific health routine. A majority, 66 per cent $(\mathrm{N}=242)$, were not on any health routine while 34 percent $(\mathrm{N}=126)$ were placed on health routine. The expectation is that those who are on a recommended health regimen due to a particular illness would be more inclined to take health action suggested in the newspapers.

Table 18.Respondents' Perception of Healthy lifestyle advices in the Newspapers

\begin{tabular}{|l|l|}
\hline Variable & Percentage \\
\hline Too hard to maintain & $37 \%$ \\
\hline Too expensive & $31 \%$ \\
\hline Less Pleasurable & $20 \%$ \\
\hline Time Consuming & $12 \%$ \\
\hline Total & $100 \%$ \\
& $(\mathrm{~N}=347)$ \\
\hline
\end{tabular}

On the respondents' perception of healthy lifestyle advice in newspapers, the result shows that 37 percent $(\mathrm{N}=$ 127) think they are too hard to maintain; thirty-one percent $(\mathrm{N}=106)$ think they are too expensive; twenty percent $(\mathrm{N}=70)$ say they are less pleasurable while 13 percent $(\mathrm{N}=44)$ believe they are time consuming.

Table 19. Respondents' who are always health conscious while making health affecting choices

\begin{tabular}{|l|l|}
\hline Variable & Percentage \\
\hline Yes & $82 \%$ \\
\hline No & $18 \%$ \\
\hline Total & $100 \%$ \\
& $(\mathrm{~N}=367)$ \\
\hline
\end{tabular}

Results in Table 19 indicate that majority of the respondents $(82 \% \mathrm{~N}=301)$ say they were always health conscious while making health-affecting choices while $18 \%(\mathrm{~N}=66)$ admit they are not always conscious of their health while making choices that might affect their health.

\subsection{Taking Health Action Suggested in the Newspapers}

The goal here is was to ascertain whether the respondents took health actions as suggested in the Newspapers. A series of questions $28-36$ were posed to the respondents to measure this. The results are indicted in Tables. 
Table 20. Respondents who have tried the Health Action as Suggested in the Newspapers

\begin{tabular}{|l|l|}
\hline Variable & Percentage \\
\hline Yes & $87 \%$ \\
\hline No & $13 \%$ \\
\hline Total & $100 \%$ \\
& $(\mathrm{~N}=363)$ \\
\hline
\end{tabular}

In the above table, 87 per cent $(\mathrm{N}=315)$ of the respondents representing a majority, had tried the health action as suggested in Newspapers while 13 percent $(\mathrm{N}=48)$ said they had never tried health actions as suggested in Newspapers healthy lifestyle discourses.

Table 21. How Often Respondent try health action suggested in the Newspapers

\begin{tabular}{|l|l|}
\hline Variable & Percentage \\
\hline Regularly & $26 \%$ \\
\hline Occasionally & $57 \%$ \\
\hline Not at all & $17 \%$ \\
\hline Total & $100 \%$ \\
& $(\mathrm{~N}=367)$ \\
\hline
\end{tabular}

On how often they tried the suggested health action, majority of the respondents, 57 percent $(\mathrm{N}=209)$ say they tried the health actions occasionally; 26 percent tried the actions regularly while 17 percent $(\mathrm{N}=61)$ did not try the health action as suggested in Newspaper healthy lifestyle discourses. The findings here is similar to the previous findings which show that a majority of the civil servants in the south east have tried health action suggested in the newspapers; however majority of the respondents only tried the actions occasionally.

Table 22. Frequency of taking health action discussed in the newspapers among respondents

\begin{tabular}{|c|c|c|c|c|c|c|}
\hline Variable & $\begin{array}{c}\text { How often } \\
\text { respondents } \\
\text { make healthy } \\
\text { food choices }\end{array}$ & $\begin{array}{c}\text { How often } \\
\text { respondents } \\
\text { avoid smoking } \\
\text { or being } \\
\text { secondary } \\
\text { smoker }\end{array}$ & $\begin{array}{c}\text { How often } \\
\text { respondents } \\
\text { stay active by } \\
\text { exercising }\end{array}$ & $\begin{array}{c}\text { How often } \\
\text { respondents } \\
\text { go for regular } \\
\text { screening and } \\
\text { testing }\end{array}$ & $\begin{array}{c}\text { How } \\
\text { respondents } \\
\text { Seek to rest, } \\
\text { relax and get } \\
\text { enough sleep }\end{array}$ & $\begin{array}{c}\text { How often } \\
\text { respondents } \\
\text { try to maintain } \\
\text { healthy weight }\end{array}$ \\
\hline Regularly & $60 \%$ & $67 \%$ & $31 \%$ & $37 \%$ & $30 \%$ & $58 \%$ \\
\hline occasionally & $36 \%$ & $13 \%$ & $60 \%$ & $60 \%$ & $57 \%$ & $36 \%$ \\
\hline Not at all & $4 \%$ & $20 \%$ & $9 \%$ & $18 \%$ & $13 \%$ & $6 \%$ \\
\hline Total & $100 \%$ & $100 \%$ & $100 \%$ & $100 \%$ & $100 \%$ & $100 \%$ \\
$(\mathrm{~N}=371)$ & $(\mathrm{N}=366)$ & $(\mathrm{N}=368)$ & $(\mathrm{N}=367)$ & $367)$ & $(\mathrm{N}=368)$ \\
\hline
\end{tabular}

In Table 22 above, readings from the data presented establish the frequency of respondents taking the various health actions suggested in the newspapers. More of the respondents regularly make healthy food choices $(60 \%)$, avoid smoking or secondary smoking (67\%) and try to maintain a healthy weight $(58 \%)$. Whereas less than half of the respondents regularly stay active $(31 \%)$, go for regular screening and testing $(37 \%)$ and seek relaxation and getting adequate sleep (30\%). This is not unconnected to content analysis result in Table 3 that shows that majority of the discourses on healthy lifestyle in the newspapers centre on healthy food choices and diet followed by physical activities and then pro health behaviours. It is possible that people will be better exposed and knowledgeable about the health choice(s) that gets more mention in the paper which will then translate to taking action by the target audience.

Also, the actions respondents take occasionally includes staying active by exercising (60\%), regular screening 
and testing (60\%) and seeking relaxation and adequate sleep (57\%). Lesser percentage of the respondents took health actions such as making healthy food choices (36\%), avoided smoking or secondary smoking (13\%) and maintained healthy weight (36\%).

Much lesser percentage of the respondents admitted they did not take the health action. The details are: making healthy food choice (4\%), avoid smoking or secondary smoking (20\%), stay active by exercising (9\%), going for regular screening (18\%), seeking relaxation and getting adequate sleep (13\%), maintaining a healthy weight (6\%)

Table 23. Why Respondents don't take any or all of the health actions on regular basis

\begin{tabular}{|l|l|}
\hline Variable & Percentage \\
\hline Too rigid & $16 \%$ \\
\hline Too expensive & $25 \%$ \\
\hline Lack of Time & $53 \%$ \\
\hline Not Necessary & $6 \%$ \\
\hline Don't Trust Advice & $0.3 \%$ \\
\hline Total & $100 \%$ \\
& $(\mathrm{~N}=348)$ \\
\hline
\end{tabular}

On the reasons why respondents don't take any or all of the health actions on regular basis, more than half of the respondents 53 per cent $(\mathrm{N}=186)$ say it was due to lack of time, 25 percent $(\mathrm{N}=86)$ say it's too expensive, too rigid 16 per cent $(\mathrm{N}=55)$ and 'Not necessary' was 6 percent $(\mathrm{N}=20)$. Only one respondent representing, $0.3 \%$ attributed it to lack of trust in the advice presented in the newspapers. This suggests that the respondents do not have the time to look in the way of healthy choices most of the time.

\subsection{Analysis of the Research Questions}

The first research question sought to know the extent to which Nigerian Newspapers discuss healthy lifestyle for disease prevention. This was subjected to content analytical study and was measured using specific categories. As shown in Tables $2-7$. The findings show that 120 discourses were found in the Newspapers studied for the period of three months out of which majority was entered on healthy food choice, diet and nutrition. Importantly, majority $(64 \%)$ of the discourses on healthy lifestyle in the Newspapers were found to be in-depth as they were either written by expert or have expert advice and opinion. It found also that most of the discourses in the Newspapers on healthy living fall between 501 - 750 words; they are not too short, neither are they too long in length. Again, most of the healthy lifestyle discourses in Nigerian Newspapers were found to have been given half page and more and $73 \%$ of these discourses were published with pictures. These bits of findings are clear indication that the Nigerian Newspapers discuss healthy lifestyle for prevention of diseases to a great extent.

The second research question was meant to find out who among the target audience were exposed to the discourses on healthy lifestyle for disease prevention. The findings on the target audience exposure shows a clear consistency in the high percentage of respondents who were exposed to Newspapers discourses. Ninety percent have read Newspaper article on healthy eating and diet, another $90 \%$ have read articles promoting active life; 88 percent have read Newspaper articles Promoting good health behaviours while 82 percent of the readers have been exposed to newspaper articles on regular screening and testing. Respondents scored high (85\%) in the measuring index which is an indication that the target audience was adequately exposed to Newspaper discourses on healthy lifestyle for disease prevention.

The third research question sought to know whether these target audience are knowledgeable of the safe habits necessary to maintain a healthy state. The analysis of the data in Table 12 revealed that most of the respondents demonstrated good knowledge of the safe habits necessary to maintain good health, thus scoring $88 \%$ (see Figure 6 ) on the measuring index. This finding and the result on exposure shows a consistent link between knowledge and exposure to newspaper discourses for disease prevention.

The fourth question that sought to know the readers' disposition towards the discourses on healthy lifestyle was measured by asking perception based questions to gauge the views and attitude of respondents towards the discourses. Thus, the data analysis in Tables $13-19$ shows that 55\% think all the healthy lifestyle discourses 
they have read in the newspapers were accurate but a significant number $(37 \%)$ was sceptical about the discourses as they did not think they were altogether true; $84 \%$ of the respondents perceive the healthy lifestyle discourses as important to their overall well being. Similarly, on the respondents' perceived usefulness of the healthy lifestyle discourses in the newspapers, 98 percent adjudged them useful. On what respondents think is responsible for their overall state of health. Analysis in Table 16 shows that 64 percent believe in the lifestyle choices they make while a majority of the respondents $82 \%$ said they are always health conscious while making health-affecting choices. Overall, the bits of data from the readers' perception of accuracy of discourse, importance of discourse, usefulness of discourse as well as their perception of what is responsible for their overall health and their health consciousness, give an insight into the disposition of the target audience to the discourses on healthy lifestyle for disease prevention.

The fifth question sought to determine whether the respondents took health action as suggested in Newspaper health discourses. Data analysis in Table 22 shows that healthy choices which include healthy eating and diet, avoiding smoking or secondary smoking and maintaining a healthy weight are actions majority of the respondents admit to be taking on regular basis $(60 \%, 67 \%$ and $58 \%$ respectively). While actions like regular exercise, going for regular screening and always seeking relaxation were taken occasionally $(60 \%, 60 \%$ and $57 \%$ respectively). This may not be unconnected to content analysis result in Table 3 that shows that majority of the discourses on healthy lifestyle in the newspapers centre on healthy food choices and diet followed by physical activities and then pro health behaviours. It is possible that people will be better exposed and knowledgeable about the health choice(s) that gets more mention in the media which then translates into taking the action as suggested in the media.

Table 23 also gave an insight into the reason why respondents do not take any or all of the health actions on regular basis. Majority of the respondents (53\%) say it is due to lack of time while a significant percentage $(25 \%)$ believes it is too expensive.

\subsection{Discussion of Findings}

The data analyzed in this study was obtained from 386 civil servants spread across three state secretariats in South-eastern Nigeria. The overall results offer a wide range of insights and conclusions.

The key research question asked was to know whether the target audience - the civil servants in south east, Nigeria make healthy life choice as suggested in Newspaper discourses. A wide range of conclusions can be drawn from the findings.

Findings from the study have led to the conclusion that a considerable amount of discourses on healthy lifestyle for disease prevention are in the Nigerian newspapers. An important insight provided by this study is that most of the discourses on healthy life choice centre on healthy eating, food and nutrition. This supports the view of Eyck (2000) that the most likely source of information regarding food and food safety matter and healthy choices is the print media.

Another insight provided in this study is the newspaper readership of civil servants in the south east. A majority of respondents who admit they read newspapers lead to the conclusion that newspapers are available to civil servants and they read them. However, this result does not bear a favourable correlation with the result that less than half of the civil servants studied read newspapers regularly. This finding is also similar to Olusoji (2012)'s findings from the study of civil servants readership in southwest Nigeria which found over 90 percent readership among civil servants. The newspaper readership rate recorded in this study and previous studies might be due to some ICT use limitations in Nigeria. As Ani et al (2007) noted that no matter the breakthrough in the electronic world, the print media readership will still keep up because of some limitations of the use of ICT in Nigeria. This finding also validates the assumption made at the early part of this work that Civil servants might have access to Newspapers and read them, which precipitated there use as population for the survey aspect of this study.

The study also found that most of the respondents were exposed to newspaper articles promoting healthy life choices. This high level of exposure is directly related to the high level of knowledge of the safe habits necessary to maintain a healthy state as found in the study. The high level of exposure demonstrated by the respondents gives insight into what they believe about healthy life and disease prevention because the knowledge questions were tilted towards the benefits of a health action. This finding is consistent with a Gallup survey conducted for American Health Magazine, (1991) where almost three fourths of the people polled believed that if they eat right, don't smoke, and get regular checkups, they have a good chance of preventing cancer. An even larger number, more than $80 \%$ believed that they can significantly reduce their chances of having a heart attack by watching their weight and blood-fat level. 
The finding also revealed that more than half of the civil servants believe that the newspaper discourses are accurate but a significant number also think that they are not completely accurate. This perception of accuracy of discourses throws an insight into what readers think of what they read in the Newspapers which can hinder them from taking the actions suggested in the Newspapers. However, the civil servants in the south east perceive the discourses as useful and important to their overall health even as a significant number of them also believe that their state of health was dependent on the choices they made. These findings lead to the conclusion that the civil servants believe that the recommended action of adopting a healthier lifestyle would prevent the diseases from coming to them.

Based on the findings on whether the respondents take health action as suggested in the Newspapers health discourses, it can be concluded that most of the civil servants in south east Nigeria take all of the health advice discussed in the newspapers but only lifestyle choices like healthy food choice, avoiding smoking or secondary smoking and trying to maintain a healthy weight were actions taken on regular basis. It should be noted however, that making a particular habit part of one's lifestyle means that one has to be taking these actions on regular basis. Then, if just a few of the choices pointed out are made on regular basis, it then means that the civil servants do not take adequate actions necessary to maintain a good health despite the level of exposure, knowledge and disposition. The 30 percent of the respondents who take the health actions on regular basis is slightly linked to the percentage (34\%) of those who are on recommended health routine. This can be translated to mean that those who have had personal experience with a health issue, showed more interest in seeking advice and information and regularly take health actions as suggested in the Newspapers.

The study's revelation that the civil servants don't take the actions often suggested in the newspapers due to lack of time, attest to this claim.

\section{CONCLUSION}

Data obtained from 386 civil servants spread across three state secretariats in the south east Nigeria showed that the civil servants believe that adopting recommended action from Newspaper health discourses would made for a healthier lifestyle that would prevent the diseases from coming to them. The civil servants did not take adequate actions necessary to maintain a good health despite the level of exposure; knowledge and disposition as an average of 30 percent of the civil servant studied took health actions on a regular basis. Those who have had personal experience with a health issue, showed more interest in seeking advice and information and regularly took health actions as suggested in Newspapers.

The conclusion therefore is that civil servants in south east Nigeria are well exposed to healthy lifestyle discourses for disease prevention and have good knowledge of the subject matter. However, this did not translate to taking adequate action because civil servants feel they lack the time to take regular actions for prevention of diseases but they are more likely to take the action if they have a particular health issue.

\section{REFERENCES}

Adeniyi, Olusegun (2007) "Why the Hell Am I Here?” Nigerian Village Square, September 07, 2007; accessed May 05, 2019 from http:/www.nigeriavillagesquare.com/index.php?option=com_content\&view=article\&id= $7117 \&$ catid $=336 \&$ Itemid $=46$.

Adum, A.N. (2011) HIV \& AIDS controversies as a probable influence on believability of HIV \& AIDS communication in southeast Nigeria. An unpublished Ph.D Dissertation, Nnamdi Azikiwe University, Awka.

Alexander, S. (2005). The role of the media in attaining the MDGs. Development, 48, 129-131.

Ani, O. E., Uchendu, C. \& Atseye, E. U. (2007). Bridging the Digital Divide in Nigeria: A study of the Internet Use in Calabar Metropolis, Nigeria. Library Management, 28(6/7), 355-365.

Bello, S. (2015). Newspaper coverage of health issues in Nigeria: A triangular approach. Presented at the Communication Seminar Series, University of Canterbury March 10, Retrieved from www.canterbury.ac.nz/

Champion, V.L. (1984) Instrument development for health belief model constructs, Advances in Nursing Science, 6, 73-85.

Cheney, D., Knapp, J., Alan., R., \& Czapla, P. (2006). Convergence in the library's news room: Enhancing news collections and services in academic libraries. College \& Research Libraries, 67 (5), 395-417.

Clarke, N. (2019) Definition of healthy lifestyle. Livesrtong.com, retrieved from 
https://www.livestrong.com/article/412212-definition-of-healthy-lifestyle/

Cooper, D.R. and Schindler, P.S. (2001) Business research methods. McGraw-Hill Higher Education, London.

Dominick, J. R (2009) Dynamics of Mass Communication: Media in the Digital Age (10th edition). New York: McGraw Hill Higher Education

Entwistle, V. (1995). Reporting research in medical journals and newspapers. British Medical Journal, 310(6984), 920-23.

Fawole, O. P., Thomas K. A. \& Ibitade A. S. (2012). Framing of Avian Influenzaa Coverage by Nigerian Newspapers. Journal of Media and Communication Studies, 4(1), $11-18$

Hales, D. (1992). An Invitation to health: Taking charge of your life (5 $5^{\text {th }}$ edition). Canada: Benjamin/Cummings Publishing Company, Inc.

Hallin, D. (2000). 'Commercialism and Professionalism in the American News reporting. Annals of Internal Medicine, 140(3), 226-8.

Igbeka, J. U. \& Ola, C. O. (2010). Use of Newspapers by Nigerian University Students: The Case of Delta State University, Anwai Campus. Library Philosophy and Practice, Annual Volume, ISSN 1522-0222

Ige, J. B. (2013). Imperative of Total Newspapering for Survival in Nigerian Newspaper Industry. Arabian Journal of Business and Management Review (OMAN Chapter), 2(8)

Janz, N. K., \& Becker, M. N. (1984). The Health Belief Model: A decade later. Health Education Behaviour, 11(1), 1-47. Doi:10.1177/109019818401100101.

Johnson, B. (2013). The Print Media in the Global Village. A paper presented at the conference of Centre for the Internet Literacy (CIL), Lagos, August 16, 2013.

Kadiri, K. K. (2011). Development News in Nigerian Newspaper: A Content Analysis on the Punch and New Nigerian Newspaper. Ilorin Journal of Sociology, 3(1), 80-101

Lupton, D. \& Chapman, S. (1995). 'A healthy lifestyle might be the death of you': Discourses on diet, cholesterol control and heart disease in the press and among the lay public. Sociology of Health \& Illness, 17(4), $477-494$ ISSN 0141-9889

MacDougal, C. (1997). Interpretative Reporting. Ottawa: Macmillan Publishing.

Melissa, C. S. (2015). Disease prevention through diet and nutrition. http://www.medicinenet.com. Retrieved 01/09/2015. 1: 25pm

Meyer, D.E. (1975). Studies in long term memory. London: John Wiley \& Sons

Moemeka, A. (1991). Perspectives in Development Communication. In S. T.K. Boafa (Ed.), Module on Development Communication. (pp. 34 - 44). Nairobi: African Council for Communication Education

Moyer, A. (1995). Accuracy of health research reported in the popular press: breast cancer and mammography. Health Communication, 7(2), 1470161.

Moynihan, R. (2003). Making medical journalism healthier. Lancet, 361(9375), 2097-8.

Niederdeppe, J. M., Farrelly, K. Y., Thomas, D., W and Wietzenkamp, D. (2007). Newspaper coverage as indirect effects of a health communication intervention: The Florida Tobacco Control Program and Youth Smoking. Communication Research, 34(4), 382 - 405

Nwabueze, C. D. (2005). The Art of Investigative Reporting: A Practical Guide. Enugu: Daisy Press.

Nwodu, L. C. (2006). Journalism Practice: News, Aesthetics, Ethics and Laws. Enugu: Rhyce Kerex.

Ogbondah, C.W. (1994). Press Freedom in West Africa: An analysis of one ramification of human rights. Issue: A Journal of Opinion, Vol.22, No.2,pp.21-26

Ohaja, E. U. (2005). Feature writing simplified. Enugu: EI Demark Publishers.

Ojua, T.A. (2006), Change and Continuity in Inheritance and Succession Practice among the Boki People of Cross River State - Nigeria. An unpublished Ph.D Dissertation, Institute of African Studies, University of Ibadan

Okonkwor, C. N. (2015, September 6). Diet and Health (2). SundaySun, 30

Olusoji, O. A. (2012). Newspaper readership in the civil service: a case study of Ekiti civil servants. Online journal of African Affairs, 1(1), 4 - 9. Http//www.onlinesearchjournals.org/OJAA 
Omenugha, K. A. \& Oji, M. (2008). News Commercialization, ethics and objectivity in Journalism Practice in Nigeria: Strange bedfellows? Estudos em Communicacao. 3, 13 - 28. http;//www.ec.ubi.ptec/03/html/ Retrieved on 3/6/2015. 2:10 pm

Oseni, A. L and Ehis, O. (2011). The Future of Print Media. Lagos: Insight Communications.

Oyero, O. (2013). The Use and Believability of Social Networks News among Nigerian Youths. Covenant Journal of Communication (CJOC), 1(1), 43-55.

Pierce, J. P. \& Gilpin, E. A. (2001). News media coverage of smoking and health. Tobacco Control, 10, $145-53$.

President's Council on Sports, Fitness \& Nutrition, Report (1993). Retrieved from:

https://www.hhs.gov/fitness/index.html

Rajini, V. (2011). Newspapers: Why India's Newspaper Industry is booming, BBC Business. Retrieved from: https://www.bbc.com/news/business-14362723.

Rice, R. E. (2001). The Internet and health communication: A framework of experiences. In Rice, R \& Katz, J. E (ed). The Internet and Health Communication: Experiences and Expectations. Thousand Oaks, CA: Sage Publications, 5-46.

Schwartz, L. M. \& Woloshin, S. (2004). The media matter: A call for straightforward medical

Stein, J. J. and Pruitt, B. E. (1999). Health Styles: Decisions for Living Well (2 ${ }^{\text {nd }}$ Edition). USA: Allyn \& Bacon Needham Heights.

Uchendu, V. C. (1963). The Igbo of SouthEast Nigeria. New York: Holt, Rinehart and Winston

Thorson, E. (2006). Print news and health psychology. Journal of Health Psychology, 11(2), 175-182

Tong, A., Chapman, S., Sainsbury, P. \& Craig, J. C. (2008). An analysis of media coverage on the prevention and early detection of CKD in Australia. American Journal of Kidney Diseases, 52(1), 159-70.

Torwel, V. \& Rodney, C. (2010). Newspaper coverage of health issues in Nigeria. African Communication Research, 3(2), 235 - 252. ISSN 1821-6544

Uwom, O. O and Oloyede, D.B (2014). Newspaper coverage of health issues in Nigeria (a study of the Guardian and the punch newspapers January 2010 to December 2011), International Journal of African and Asian Studies, 4, 83-89.

Winett, L. B. \& Wallack, L. (1996). Advancing public health goals through the mass media. Journal of Health Communication, 1(2), 173-96. 